This report was prepared as an account of work sponsored by an agency of the United States Government. Neither the United States Government nos any agency thereof, nor any of their employees, makes any warranty, express or implied, or assumes any legal liability or responsibility for the accuracy, completeness, or usefulness of any information, apparatus, product, or process disclosed, or represents that its use would not infringe privately owned rights. Reference herein to any specific commercial product, process, or service by trade name, trademark, manufacturer, or otherwise does not necessarily constitute or imply its endorsement, recommendation, or favoring by the United States Government or any agency thereof. The views and opinions of authors expressed herein do not necessarily state or reflect those of the United States Government or any agency thereof.

\title{
ON IMPACT TESTING OF SUBSIZE CHARPY V-NOTCH TYPE SPECIMENS*
}

\author{
Mikhail A. Sokolov and Randy K. Nanstad
}

Metals and Ceramics Division

OAK RIDGE NATIONAL LABORATORY

P.O. Box 2008

Oak Ridge, TN 37831-6151

\footnotetext{
*Research sponsored by the Office of Nuclear Regulatory Research, U.S. Nuclear Regulatory Commission, under Interagency Agreement DOE 1886-8109-8L with the U.S. Department of Energy under contract DE-AC05-84OR21400 with Lockheed Martin Energy Systems.
} 
Mikhail A. Sokolov ${ }^{1}$ and Randy K. Nanstad ${ }^{1}$

ON IMPACT TESTING OF SUBSIZE CHARPY V-NOTCH TYPE SPECIMENS

REFERENCE: Sokolov, M. A., and Nanstad, R. K., "On Impact Testing of Subsize Charpy V-Notch Type Specimens," Effects of Radiation on Materials: 17th Volume, ASTM STP 1270, David S. Gelles, Randy K. Nanstad, Arvind S. Kumar, and Edward A. Little, Editors, American Society for Testing and Materials, Philadelphia, 1995.

ABSTRACT: The potential for using subsize specimens to determine the actual properties of reactor pressure vessel steels is receiving increasing attention for improved vessel condition monitoring that could be beneficial for light-water reactor plant-life extension. This potential is made conditional upon, on the one hand, by the possibility of cutting samples of small volume from the internal surface of the pressure vessel for determination of actual properties of the operating pressure vessel. On the other hand, the plant-life extension will require supplemental surveillance data that cannot be provided by the existing surveillance programs. Testing of subsize specimens manufactured from broken halves of previously tested surveillance Charpy V-notch (CVN) specimens offers an attractive means of extending existing surveillance programs. Using subsize CVN type specimens requires the establishment of a specimen geometry that is adequate to obtain a ductile-to-brittle transition curve similar to that obtained from full-size specimens. This requires the development of a correlation of transition temperature and upper-shelf toughness between subsize and full-size specimens. The present study was conducted under the Heavy-Section Steel Irradiation Program. Different published approaches to the use of subsize specimens were analyzed and five different geometries of subsize specimens were selected for testing and evaluation. The specimens were made from several types of pressure vessel steels with a wide range of yield strengths, transition temperatures, and upper-shelf energies (USEs). The effects of specimen dimensions, including depth, angle, and radius of notch have been studied. The correlation of transition temperature determined from different types of subsize specimens and the full-size specimen is presented. A new procedure for transforming data from subsize specimens was developed and is presented. The transformed data are in good agreement with data from full-size specimens for materials that have USE levels $<200 \mathrm{~J}$.

${ }^{1}$ Metals and Ceramics Division, Oak Ridge National Laboratory, Oak Ridge, TN 37831-6151. 
KEYWORDS: ductile-to-brittle transition temperature, subsize specimens, Charpy V-notch, correlation, normalization

\section{INTRODUCTION}

The potential for using subsize specimens to determine the actual properties of reactor pressure vessel (RPV) steels is receiving increasing attention for improved vessel condition monitoring that could be beneficial to light-water reactor (LWR) plant-life extension. This potential is made conditional upon several reasons. It is well known that annealing of Soviet-built reactors [1-2] led to significant recovery of irradiation embrittlement and to extension of plant life. This suggests that annealing of RPVs might be a very attractive way to extend plant life for some U.S. LWRs $[3,4]$. However, practical implementation of annealing includes some regulatory aspects. One of those is extension of the surveillance program so that properties of the RPV can be monitored after annealing. Machining of subsize specimens from the broken halves of previously tested Charpy surveillance specimens as well as use of sample reconstitution techniques are the most feasible ways to resolve this problem. Additionally, subsize specimens could be used in performance experiments to study the general behavior of RPV steels after reirradiation. Such experiments usually require simultaneous irradiation of a large number of specimens under the same conditions, as well as intermediate annealing of a portion of them after the first cycle of irradiation and after the second reirradiation. Another application for subsize specimens is also associated with annealing. The subsize specimens can be used to confirm the beneficial effects of vessel annealing by cutting pieces of small volume from the inside surface of the vessel before and after annealing $[5,6]$ as well as periodically during reoperation of the annealed vessel. In the last case, it could be an alternative to the standard surveillance program.

The main issue for the feasibility of using subsize Charpy V-notch (CVN) specimens to determine properties of RPV steels is a correlation of transition temperature and upper-shelf energy (USE) between subsize and full-size specimens. The present study, conducted under the Heavy-Section Steel Irradiation (HSSI) Program, analyzed different published approaches to the use of subsize CVN specimens. Five different geometries of subsize specimens from 11 material conditions were selected for testing and evaluation. The effects of specimen size and notch dimensions, including depth, angle, and root radius, on the correlation with data from full-size specimens have been studied.

\section{MATERIALS}

Four types of RPV steels were studied: (1) American Society for Testing and Materials (ASTM) A 533 grade B class 1 plates (one of them after quenching and tempering at $950^{\circ} \mathrm{C}$ ), (2) specially heat-treated steel with A 508 class 2 chemical composition, (3) a Russian forging, designated 15Kh2MFA, and (4) a submerged-arc weld. All of these RPV steels were studied previously at Oak Ridge National Laboratory 
(ORNL) using standard specimens under different tasks of the Heavy-Section Steel Technology (HSST) and HSSI programs, sponsored by the U.S. Nuclear Regulatory Commission (NRC). The materials were selected to have a relatively wide range of transition temperatures and USEs as measured with standard full-size Charpy specimens as well as a range of yield strengths. Typically the properties of many RPV steels in the as-produced state are quite similar. To increase the range of properties, some steels were studied in the quenched-only or quenched-and-tempered condition. As a result, the USEs varied from 73 to $330 \mathrm{~J}$, the transition temperatures varied from -46 to $58^{\circ} \mathrm{C}$, and the yield strengths varied from 410 to $940 \mathrm{MPa}$. Table 1 lists the types and properties of the different materials.

\section{SPECIMEN DESIGN}

The ASTM Method for Notched Bar Impact Testing of Metallic Materials (E 23-93a) [7] allows the use of subsize specimens when the amount of material available does not permit making the standard impact test specimens, but the "results obtained on different sizes of specimens cannot be compared directly." Therefore, the use of subsize specimens recommended by ASTM E 23 requires correlating the results with standard specimens. According to ASTM E 23, the length, notch angle, and notch root radius for subsize specimens are the same as for full-size specimens, which restricts the range of possible subsize specimen dimensions. A key feature of subsize specimens for RPV applications is based on the ability to use halves of broken full-size surveillance specimens. As a result, several attempts have been made to develop subsize impact specimens with geometries acceptable for nuclear application, for example, refs. [6,8-15]. Specimens were varied by all dimensions and are as small as $1 \times 1 \times 20 \mathrm{~mm}[14,15]$. However, there are some limitations on the dimensions of subsize specimens for RPV materials.

First, they should be large enough to be tested on commercially produced equipment in hot cell conditions. For example, the USE of $1 \times 1 \times 20 \mathrm{~mm}$ specimens could be as low as $0.16 \mathrm{~J} \mathrm{[15]}$ for steel with a standard specimen USE equal to $200 \mathrm{~J}$. It would be even smaller for so-called low upper-shelf welds, where the USE of standard specimens could decrease to $\sim 70 \mathrm{~J}$ due to irradiation. For 1 - by 1 -mm cross-section specimens, the USE might be $<0.1 \mathrm{~J}$, and in the transition region it would be much less than $0.1 \mathrm{~J}$.

ASTM E 23 requires that the specimen be broken within $5 \mathrm{~s}$ after removal from the conditioning medium. A reduction of size resulting in a significant increase in the surface area to volume ratio may lead to excessive temperature losses prior to impact.

Another important limitation in decreasing specimen size is the extent of the microstructural inhomogeneities. For example, a study of a special heat of A 508 forging steel $[16,17]$ indicated that carbon segregates in slender bands about $0.25 \mathrm{~mm}$ wide. Investigation of the Midland RPV weld metal [18] showed that the cross sections of individual weld passes could be several millimeters. Testing of full-size CVN specimens 
tends to give average properties of the material, but test results from very small subsize specimens may be dependent on the location of the specimens within the material.

Thus, the practical lower bound for the cross-sectional dimensions of subsize specimens for irradiated RPV steels may be limited to about $3 \mathrm{~mm}$. As far as the length of a subsize specimen, it should be no longer than one-half of the standard CVN specimen (to allow for machining from a broken specimen). Taking into account all these considerations, five designs of subsize specimens were selected for this study (see Fig. 1). The type 1 specimen is $25.4 \mathrm{~mm}$ long with a 5 - by $5-\mathrm{mm}$ cross section, a 0.8 -mm-deep $30^{\circ}$ notch, and a root radius of $0.1 \mathrm{~mm}$. Two type 1 specimens could be machined from one broken full-size CVN specimen. The type 2 specimen has a length of $25.4 \mathrm{~mm}$, a 3.3by $3.3-\mathrm{mm}$ cross section, a $0.5-\mathrm{mm}$-deep $30^{\circ}$ notch, and a radius of $0.08 \mathrm{~mm}$. Eight type 2 specimens could be machined from one broken full-size CVN specimen. One advantage of choosing types 1 and 2 specimens is the accumulated experience of using these subsize specimens in the United States [12,19-23] and Japan [14,15-24] for studies of fusion reactor materials. The type 3 specimen has a length of $27 \mathrm{~mm}$, a $5-$ by $5-\mathrm{mm}$ cross section, a $1-\mathrm{mm}$-deep $45^{\circ}$ notch, and a notch root radius of $0.25 \mathrm{~mm}$. This type of specimen has exactly the same geometry as the smallest ASTM E 23 subsize specimen, but is one-half as long. Two type 3 specimens could be machined from one broken full-size CVN specimens. Experience with this type of subsize specimen has been accrued in Russia [2,6] for RPV steels. The type 4 specimen has a length of $26 \mathrm{~mm}$, a 3- by 4-mm cross section, a 1 -mm-deep $60^{\circ}$ notch, and a root radius of $0.1 \mathrm{~mm}$. Up to 12 type 4 specimens could be machined from one broken full-size CVN specimen. Experience with this type of subsize specimen has accrued in Europe [5,11,25] and Russia [6] for different low-alloy steels, including RPV steels. The type 5 specimen has a length of $55 \mathrm{~mm}$, a 5 - by 5 -mm cross section, a $1-\mathrm{mm}$-deep $45^{\circ}$ notch, and a root radius of $0.25 \mathrm{~mm}$. This is the smallest subsize specimen recommended by ASTM E 23. A major disadvantage of this design is that it is not possible to make this type of subsize specimen from a broken full-size CVN specimen without reconstitution. Nevertheless, specimens of this design were studied for two materials.

\section{TESTING PROCEDURE}

All subsize specimens were tested on a specially modified pendulum-type instrumented impact machine [12]. The modified anvils supported the types 1 and 3 subsize specimens so that their relative position with respect to the pendulum was the same as for the full-size specimen; that is, the center of percussion of the pendulum was maintained at the center of the point of impact, with the specimen just touching the striker with the pendulum hanging free. The types 2 and 4 subsize specimens were tested using the same anvils, resulting in the center of the point of impact being slightly lower and further ahead than the center of percussion of the pendulum when hanging free. Similarly, the offset was $2.5 \mathrm{~mm}$ for the type 5 subsize specimens tested using the full-size anvils. These offsets were estimated to produce errors $<0.1 \mathrm{~J}$ [26]. The span (minimum distance between the radii of the anvils) was $20 \mathrm{~mm}$ for types 1,2 , and 3 and $22 \mathrm{~mm}$ for type 4 . The thickness 

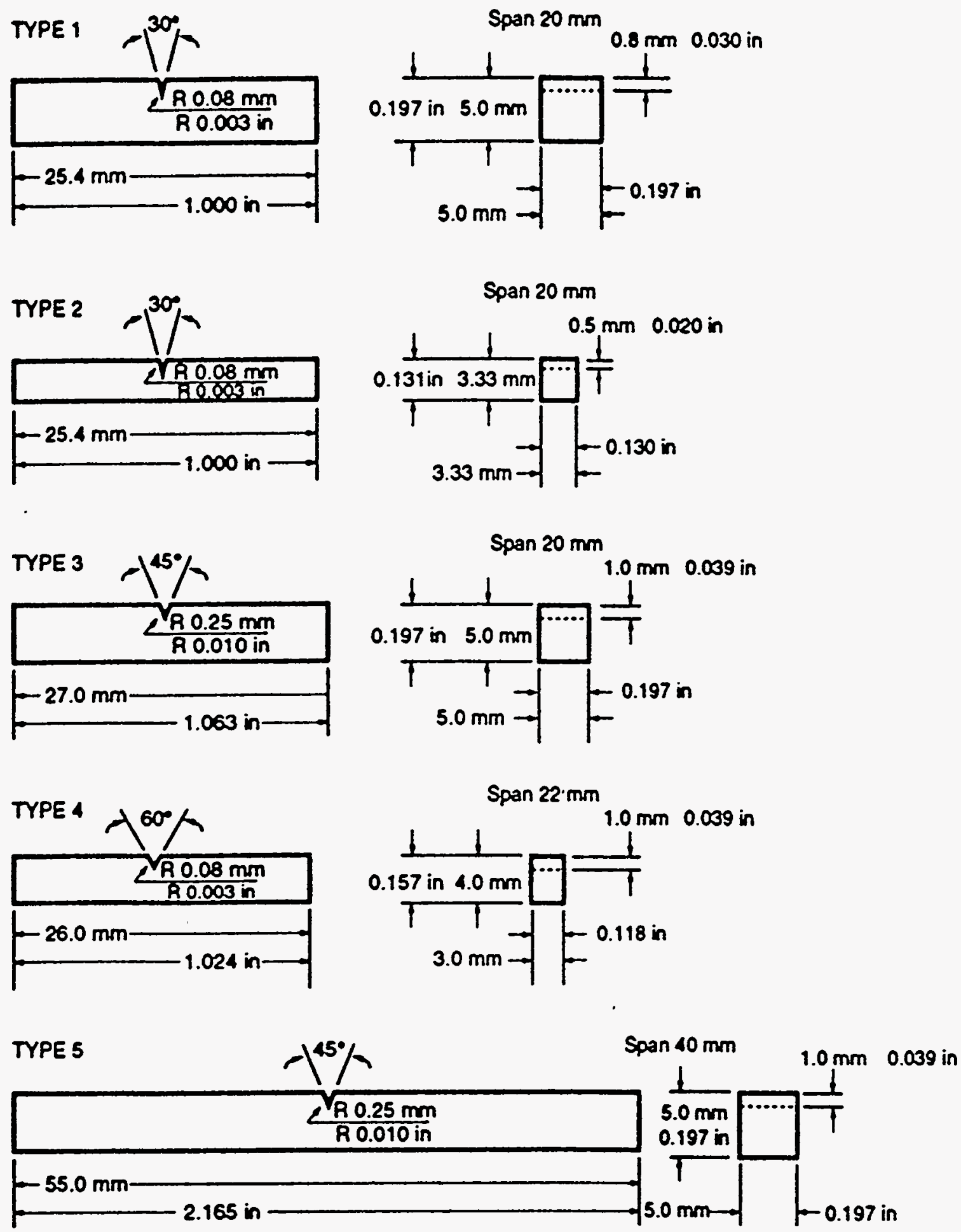

FIG. 1--Dimensions of subsize specimens used in this study. 
of the ASTM E 23 striker was reduced to $4 \mathrm{~mm}$ to allow clearance of the specimen halves between the anvils. The radii of the striker and the anvils, however, were maintained in accordance with ASTM E 23. The type 5 specimens were tested at full capacity of the machine $[407 \mathrm{~J}(300 \mathrm{ft}-\mathrm{lb})]$ and an impact velocity of $5.5 \mathrm{~m} / \mathrm{s}(18 \mathrm{ft} / \mathrm{s})$. All other subsize specimens were tested at a lower potential energy [69 J $(51 \mathrm{ft}-\mathrm{lb})]$, with a corresponding reduction of the impact velocity to $2.24 \mathrm{~m} / \mathrm{s}(7.4 \mathrm{ft} / \mathrm{s})$.

The impact data for each material condition and specimen type were fitted with a hyperbolic tangent function to obtain transition temperatures and upper-shelf energies:

$$
\mathrm{Y}=\frac{\mathrm{US}+\mathrm{LS}}{2}+\frac{\mathrm{US}-\mathrm{LS}}{2} \cdot \tanh \left[\frac{\mathrm{T}-\mathrm{T}_{\mathrm{MT}}}{\mathrm{C}}\right]
$$

where $\mathrm{T}$ is test temperature and US, $\mathrm{LS}, \mathrm{T}_{\mathrm{MT}}$, and $\mathrm{C}$ are fitting parameters. Parameters US and LS can be upper- and lower-shelf values of energy, lateral expansion, or percent shear; $\mathrm{T}_{\mathrm{MT}}$ is the temperature at the middle of the transition range, and $\mathrm{C}$ is one-half of the transition zone width. All hyperbolic tangent analyses for full-size specimens were conducted with the lower shelves fixed at $2.7 \mathrm{~J}$ and $0.061 \mathrm{~mm}$ for energy and lateral expansion, respectively. All hyperbolic tangent analyses for subsize specimens were conducted with the lower shelves fixed at $0.1 \mathrm{~J}$ and $0.0 \mathrm{~mm}$ for energy and lateral expansion, respectively. Upper and lower shelves of percent shear fracture were always fixed at 100 and $0 \%$, respectively.

\section{EFFECT OF SPECIMEN DIMENSIONS}

One objective of this study was to determine the effects of specimen dimensions on the Charpy impact results. Analyses of these effects will be used in the development of a methodology for determination of the ductile-to-brittle transition temperature (DBTT) and USE of full-size specimens using the test data from subsize specimens.

More obvious is the effect of the notch depth (a) on the USE. The sensitivity of the USE to the V-notch depth was studied on type 3 specimens of HSST Plate 02 (Fig. 2). One set of specimens was made with a $1.7-\mathrm{mm}$-notch (0.065 in.) and a second set was made with a $0.8-\mathrm{mm}$-deep $(0.030$-in.) notch. The results were compared with results for the common 1.0 -mm-deep (0.039-in.) notch. Increasing the depth significantly reduced the USE from $31 \mathrm{~J}$ for $\mathrm{a}=0.8 \mathrm{~mm}$ to $13 \mathrm{~J}$ for $\mathrm{a}=1.7 \mathrm{~mm}$. The temperatures at the middle of the transition region, $\mathrm{T}_{\mathrm{MT}}$, were $-31,-6$, and $-19^{\circ} \mathrm{C}$ for specimens with notch depths $0.8,1.0$, and $1.7 \mathrm{~mm}$, respectively. These changes in transition temperature are mainly due to changes in the USE rather than the effect of the notch depth on the transition behavior. 
In this case no effect of span would be expected, and no effect is observed (Fig. 5). Another example of the effect of span on impact properties is given by a comparison on data from types 3 and 5 subsize specimens. The only difference between these specimens is that type 3 specimens have one-half the span of type 5 . The impact curves of types 3 and 5 weld $72 \mathrm{~W}$ specimens are presented in Fig. 6 . Figure 7 presents the impact curves of types 3 and 5 specimens of HSST Plate 02. The type 5 specimens were cut from the half-thickness region in the plate. The type 3 specimens of this plate were cut from the broken halves of tested type 5 specimens. In Figs. 6 and 7, these results did not show any difference between types 3 and 5 . The $5-$ by $5-\mathrm{mm}$ specimens break even on the upper shelf, so no effect of span is observed.

One set of HSST Plate 02 type 3 specimens was tested at an impact velocity of $5.5 \mathrm{~m} / \mathrm{s}(18 \mathrm{ft} / \mathrm{s})$, while another set was tested at $2.25 \mathrm{~m} / \mathrm{s}(7.4 \mathrm{ft} / \mathrm{s}$ ) (the common impact velocity for subsize specimens in this study). The results show no sensitivity of impact properties to the increase of impact velocity from 2.25 to $5.5 \mathrm{~m} / \mathrm{s}$ (Fig. 8).

\section{CORRELATION OF ABSORBED ENERGY BETWEEN FULL-SIZE AND SUBSIZE SPECIMENS}

The absence of standardization for subsize specimen results in various correlations of data between subsize and standard specimens. Generally, the existing correlations of USE between full-size and subsize specimens can be divided into two categories. One method widely used in Europe [5-7,11,25] consists of establishing an empirical ratio between USE

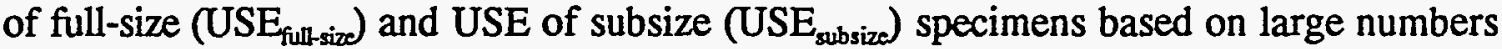
of tests. The second approach, primarily used by North American $[12,13,19-23,27]$ and Japanese $[14,15,24]$ researchers, consists of correlation of the ratio between USE of full-size and subsize specimens with the ratio of different geometrical parameters of full-size and subsize specimens:

$$
\frac{\text { USE }_{\text {full size }}}{U_{\text {SUE }}}=\frac{f(\text { geometric parameters })_{\text {full size }}}{f(\text { geometric parameters })_{\text {subsize }}} .
$$

In other words, the ratio of geometrical parameters can be used as a normalization factor (NF) to determine USE of full-size specimens based on the results of testing subsize specimens :

$$
\mathrm{USE}_{\text {full size }}=\mathrm{NF} \times \mathrm{USE}_{\text {subsize }} .
$$

Published ratios of geometric parameters of full-size to subsize specimens or normalization factors are shown in Table 2 and described below. 


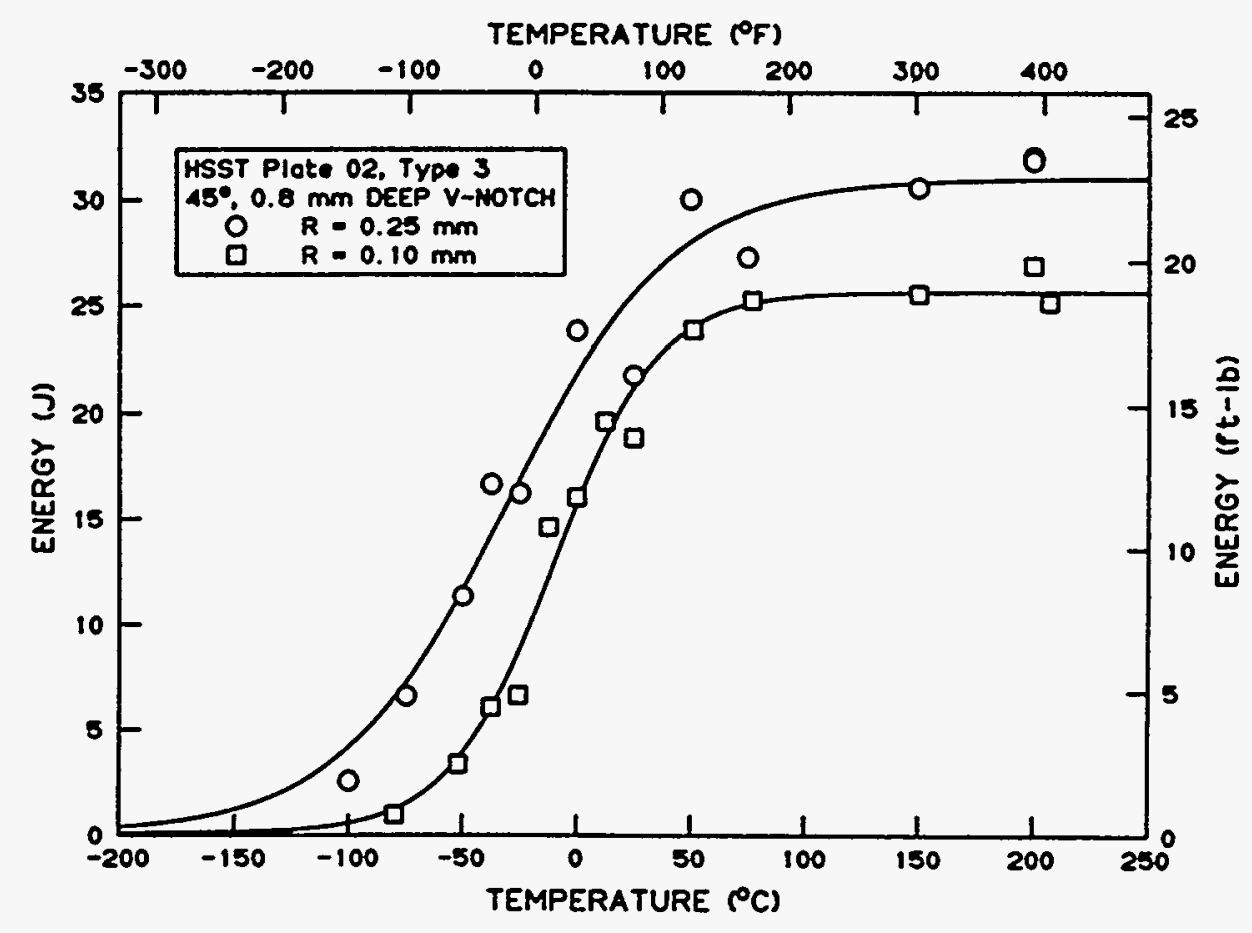

FIG. 3--Impact curve for type 3 specimens from HSST Plate 02, quarter-thickness location, with 0.25 - and $0.10-\mathrm{mm}$ V-notch root radii.

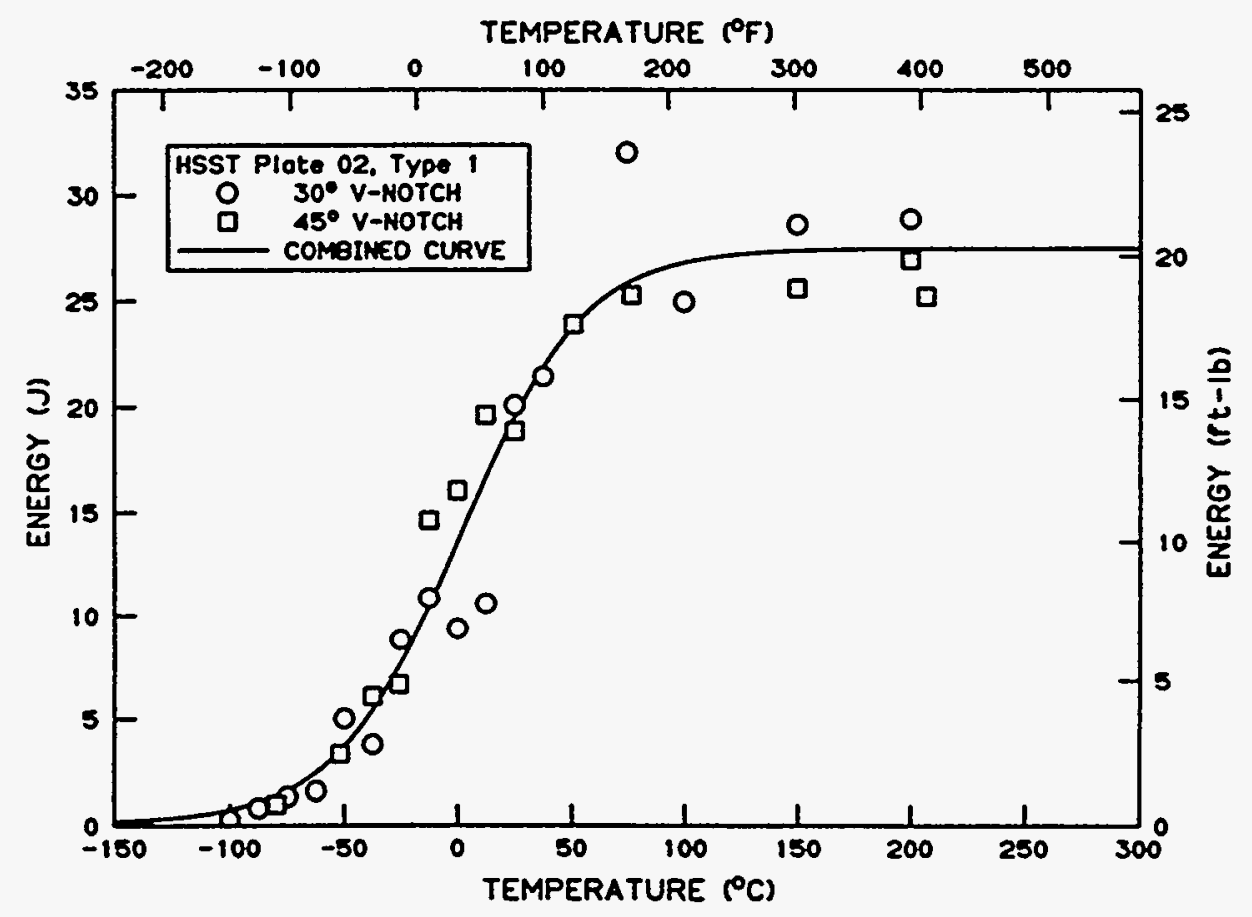

FIG. 4-Impact curve for type 1 subsize specimens from HSST Plate 02, quarter-thickness location, with 30 and $45^{\circ} \mathrm{V}$-notch angles. 


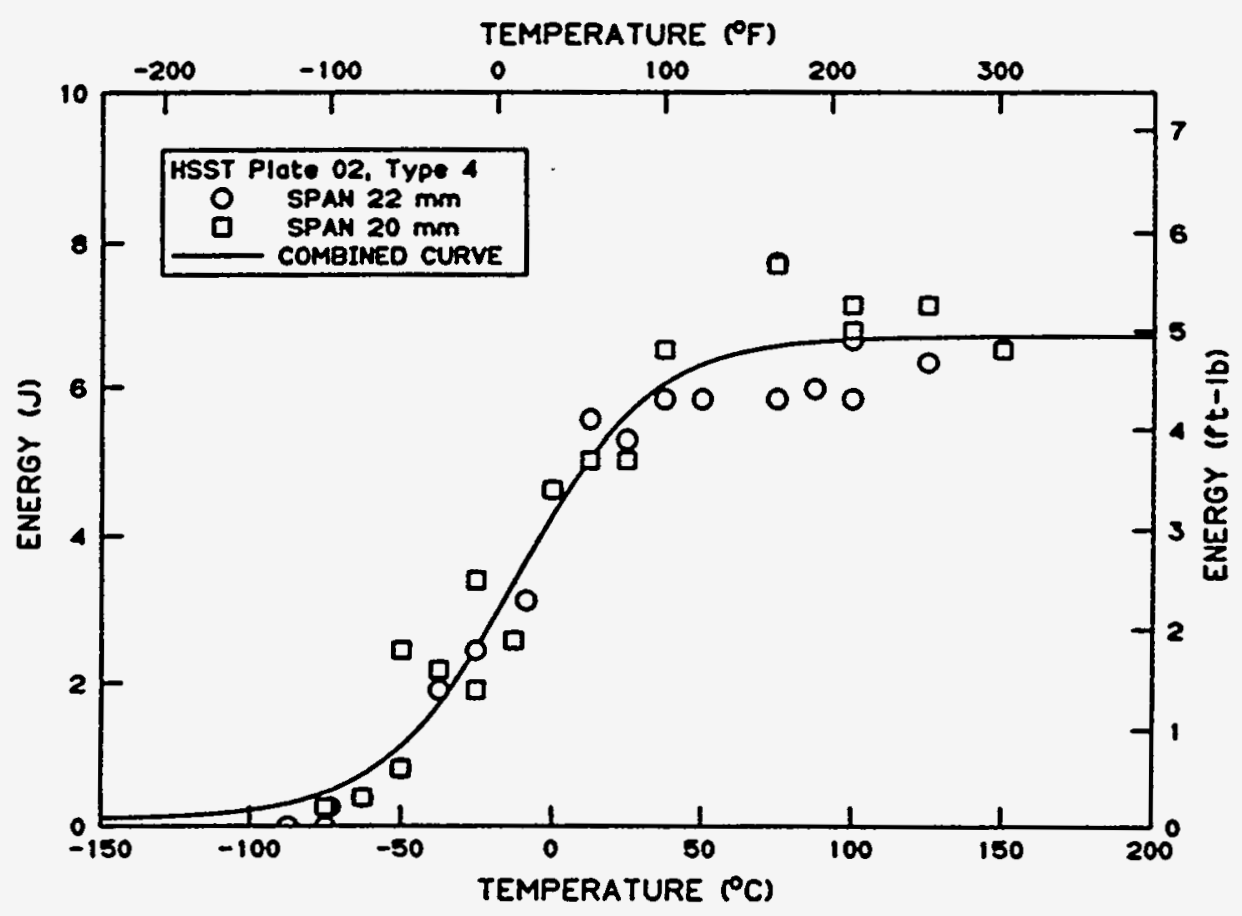

FIG. 5--Impact curve for type 4 specimens from HSST Plate 02, quarter-thickness location, tested at 22- and 20-mm span.

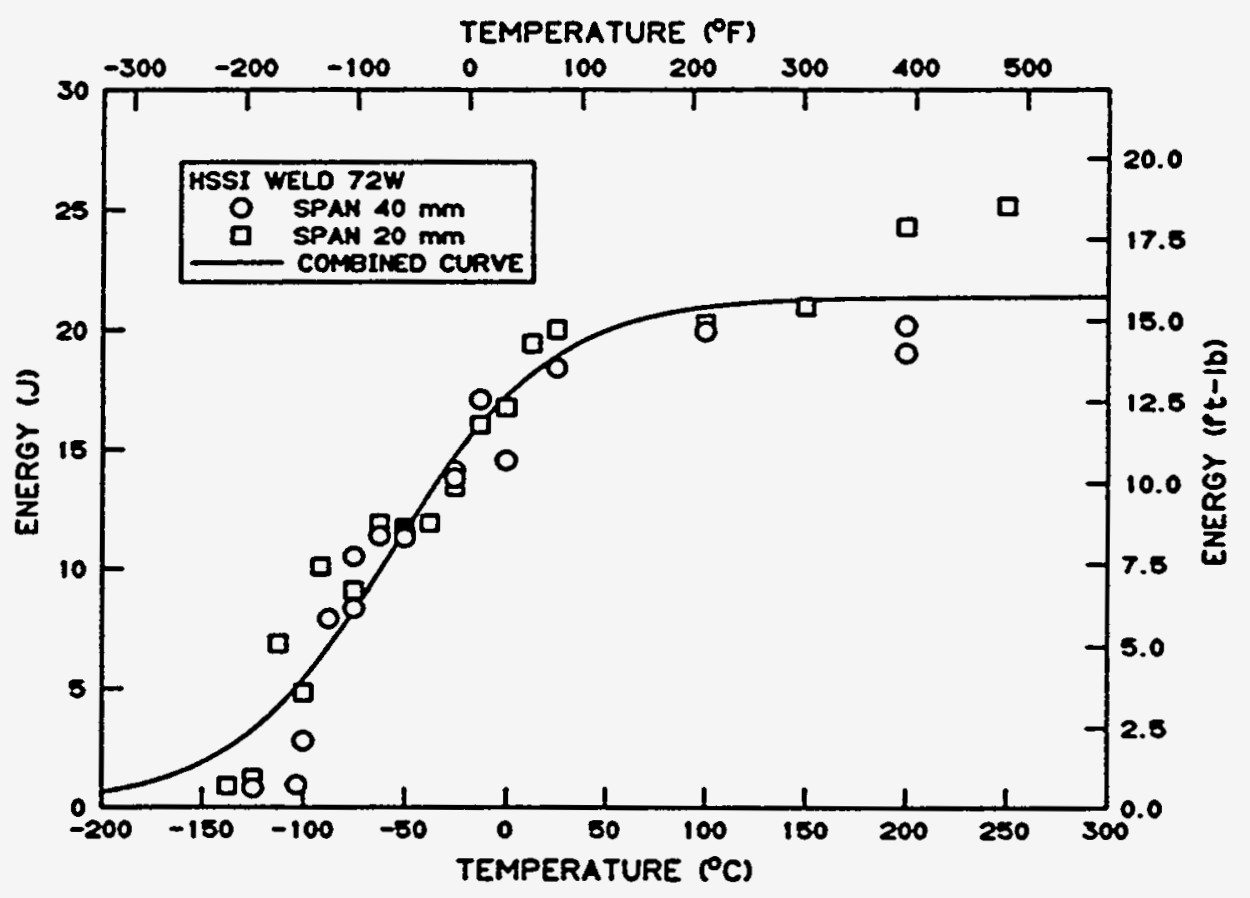

FIG. 6--Impact curve for type 3 and type 5 specimens of weld $72 \mathrm{~W}$ tested at 40 - and 20-mm span. 


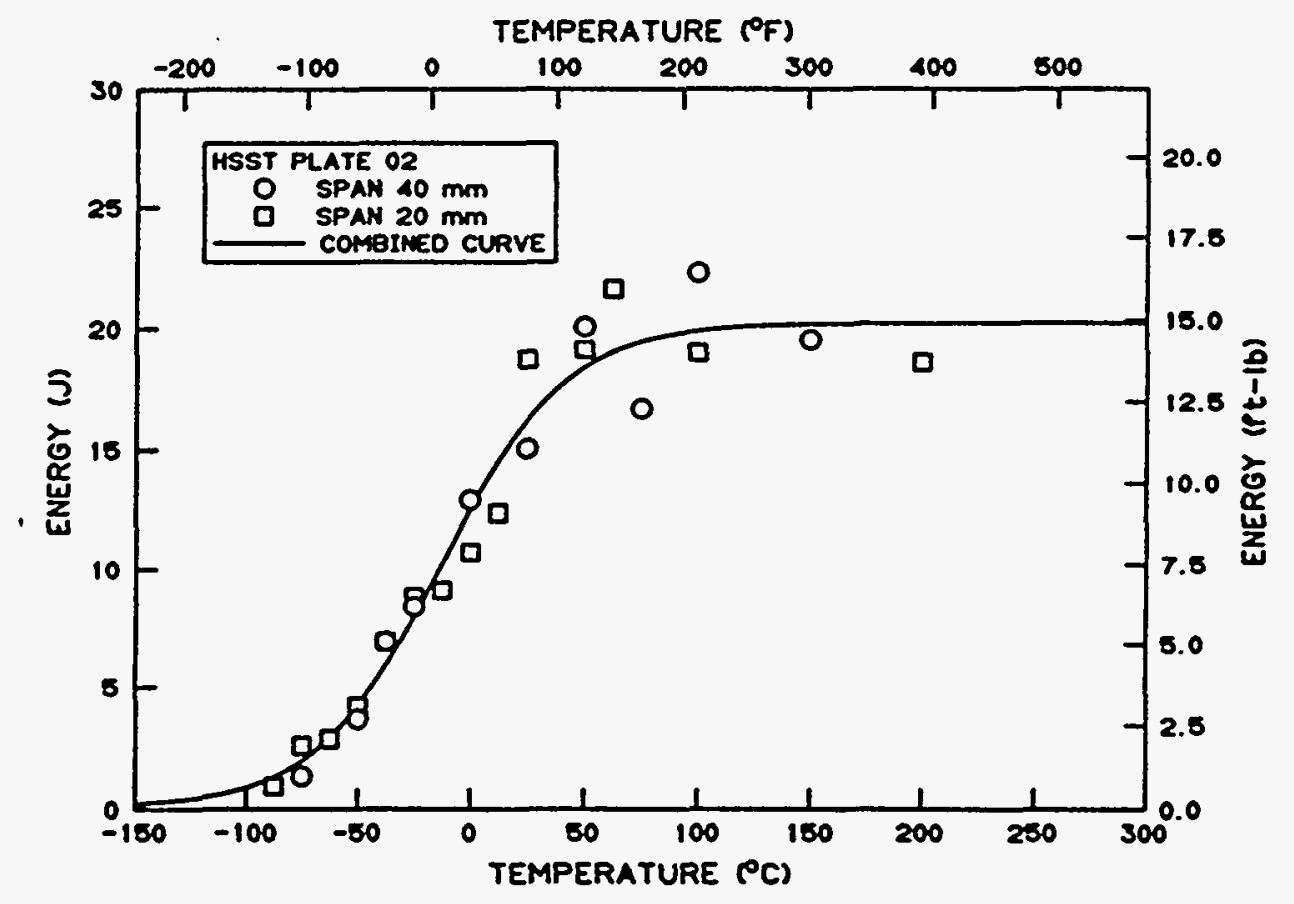

FIG. 7-Impact curve for type 3 and type 5 specimens from HSST Plate 02, half-thickness location, tested at $20-$ and $40-\mathrm{mm}$ span.

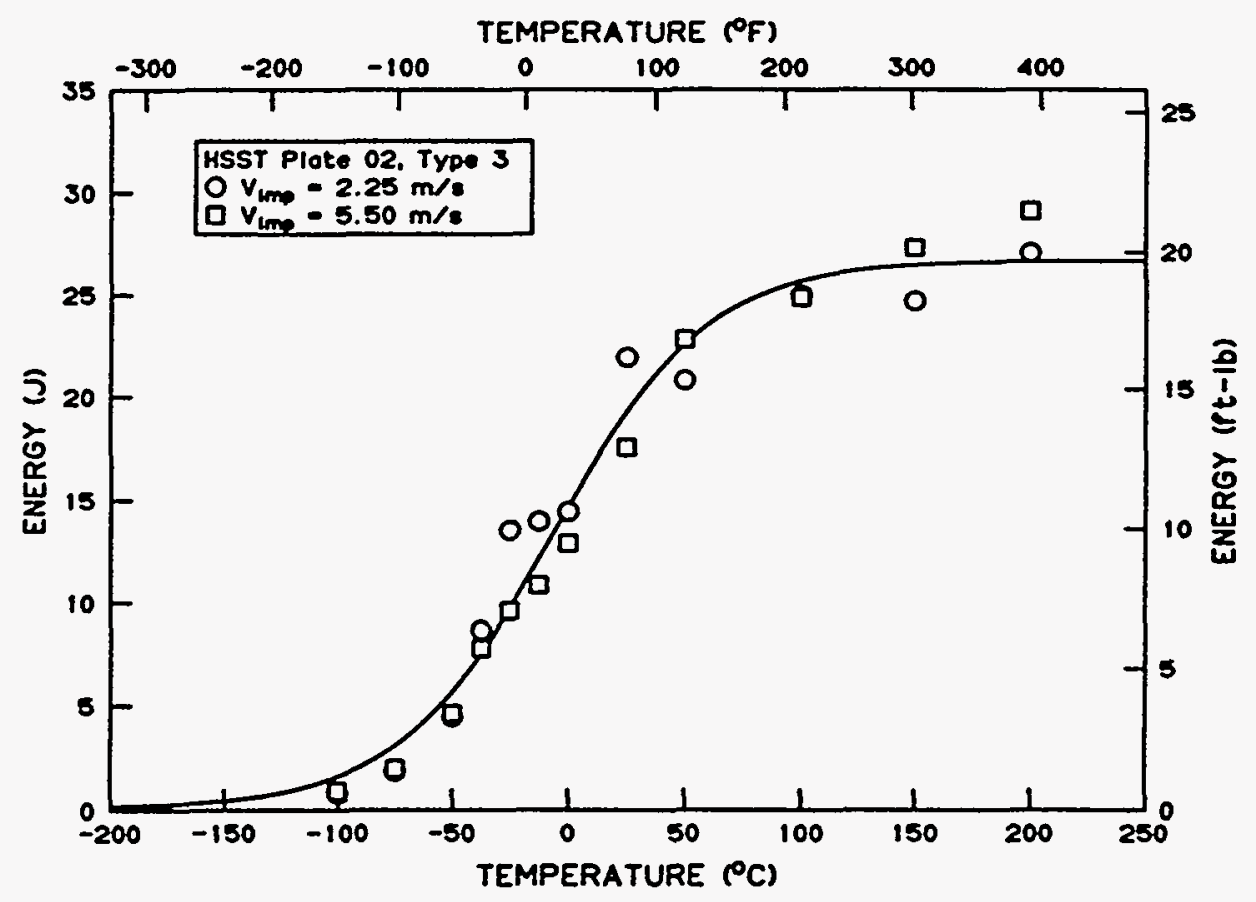

FIG. 8--Absorbed energy versus test temperature for type 3 specimens of HSST Plate 02, quarter-thickness location, test at impact velocities of 5.5 and $2.25 \mathrm{~m} / \mathrm{s}$. 
Corwin et al. [12,23] compared two normalization factors. The first factor was equal to the ratio of the fracture area $(\mathrm{Bb})$ of the full-size specimen to that of the subsize specimen, where $B$ is the width and $b$ is the depth of the ligament below the notch of the specimen (see Fig. 9). The second was the ratio of the nominal fracture volume $\left[(\mathrm{Bb})^{3 / 2}\right]$ of the full-size to the subsize specimen. It was shown that use of the normalization factor $(\mathrm{Bb})^{3 / 2}$ gave good correspondence. Normalization by $\mathrm{Bb}$ gave poor agreement for USE data.

Lucas et al. $[13,27]$ also used a normalization factor equal to the ratio of the fracture volume of full-size to subsize specimens, but expressed the nominal fracture volume as $\mathrm{Bb}^{2}$.

Louden et al. [21] suggested a normalization factor equal to the ratio of $\mathrm{Bb}^{2} / \mathrm{LK}_{\mathrm{t}}$ of full-size to subsize specimens, where $L$ is the span and $K_{t}$ is the elastic stress concentration factor [29], which is dependent on ligament size $b$ and notch radius $R$. The present study has shown (see Fig. 7) that Charpy data, including USE, of specimens tested at spans that differed by a factor of $2(20$ and $40 \mathrm{~mm})$ did not depend on span. However, the USE depends on ligament size b (see Fig. 2) and notch radius R (see Fig. 3), which might support using $\mathrm{K}_{\mathrm{t}}$. Nevertheless, it is not clear how an elastic stress concentration factor can be related to behavior on the upper shelf, where fracture is taking place in a ductile manner dominated by plastic strain.

Kumar et al. $[20,22,28]$ have developed an interesting approach to predict the USE of full-size specimens by using both notched and precracked subsize specimens. They suggest that this allows a separation of the USE into energies for crack initiation and crack propagation. This approach is based on the assumption that the energy for crack initiation normalized by fracture volume of the specimen (F.V.) is equal for full-size and subsize specimens. Energy for crack initiation can be determined from the difference between the USE of notched specimens (USE) and precracked specimens (USE p $_{\mathrm{p}}$, that is:

$$
\left[\frac{\mathrm{USE}-\mathrm{USE}_{\mathrm{p}}}{\text { F.V. }}\right]_{\text {full size }}=\left[\frac{\mathrm{USE}-\mathrm{USE}_{\mathrm{p}}}{\text { F.V. }}\right]_{\text {subsize }} \text {, }
$$

where fracture volume, F.V., is equal to $\mathrm{Bb}^{2}$. Additionally, it was found that the ratio of the USE of notched specimens to the USE of precracked specimens (USE ${ }_{p}$ ) did not depend on specimen size, namely:

$$
\left[\frac{\mathrm{USE}}{\mathrm{USE}_{\mathrm{p}}}\right]_{\text {full size }}=\left[\frac{\mathrm{USE}}{\mathrm{USE}_{\mathrm{p}}}\right]_{\text {subsize }} .
$$




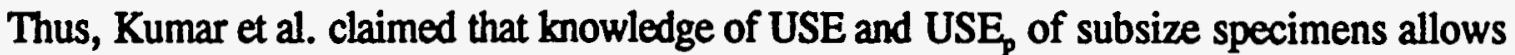
the use of Eqs. (4) and (5) to determine the USE of full-size specimens. Examination shows, however, that Eqs. (4) and (5) are interdependent and can be transformed into one equation:

$$
\left[\frac{\mathrm{USE}}{\mathrm{F} . \mathrm{V} .}\right]_{\text {full size }}=\left[\frac{\mathrm{USE}}{\mathrm{F} . \mathrm{V}}\right]_{\text {subeize }} \text {, }
$$

which is the same as Lucas et al. [13,27] proposed previously for a nominal fracture volume of $\mathrm{Bb}^{2}$ and does not require testing of precracked specimens.

Kayano et al. [14] have proposed a normalization factor that incorporates not only fracture volume but elastic $\left(\mathrm{K}_{\mathrm{J}}\right)$ and plastic $(\mathrm{Q})$ stress concentration factors as well. For the plastic stress concentration factor, the following expression based on slip-line field theory for a notched specimen [30] was used:

$$
Q=1+\frac{\pi-\theta}{2} \text {, }
$$

where $\theta$ is the notch angle in radians. Some uncertainty remains as to the exact value of $\mathrm{Q}$ in CVN testing. Slip-line field theory also assumes elastic-perfectly plastic behavior, and neglects work hardening, which is clearly not a valid assumption for most materials. Additionally, slip-line field theory can only be used when fracture occurs exactly at the point of general yielding. This will apply only at one specific temperature for a given material, not over the whole transition regime. In any case, implementation of $Q$ as in Eq. (7) includes the effect of notch angle on USE. However, the results of the present study did not show such a dependence over the limited range of notch angles examined.

In the present work, different normalization factors described above as well as modifications by the authors were implemented in the analysis of the data (see Table 2). Table 3 summarizes the results of measured USE values for full-size and subsize specimens of the steels investigated in the present study. For all types of subsize specimens, a linear dependence between the USE of full-size and subsize specimens is observed except for two points with USEs of full-size specimens higher than $200 \mathrm{~J}$. Values of USE higher than $200 \mathrm{~J}$ for full-size specimens require special consideration. Specimens tested in the upper-shelf region show large amounts of plastic deformation at the support points and at the contact area with a striker. These features are associated with the specimen "wrapping around" the striking edge and squeezing through the anvils. All interactions between the specimen, striker, and the anvils will require additional energy as reflected by the absorbed energy value [31,32]. Specimens with high USE values will have significant amounts of energy associated with such interactions in addition to the fracture process at the notch. 
TABLE 2--Comparison of different normalization factors for USE as ratios of different specimen dimensions

\begin{tabular}{|c|c|c|c|c|c|c|c|c|c|}
\hline $\begin{array}{c}\text { Geometric } \\
\text { parameter, } \\
\text { G.P. }\end{array}$ & $\mathrm{Bb}$ & $\mathrm{Bb}^{2} / \mathrm{LK}_{4}$ & $(\mathrm{Bb})^{3 / 2} / \mathrm{LK}_{\mathrm{t}}$ & $\mathrm{Bb}^{2}$ & $(\mathrm{Bb})^{3 / 2}$ & $\mathrm{Bb}^{2} / \mathrm{Q}$ & $(B b)^{3 / 2} / Q$ & $\mathrm{Bb}^{2} / \mathrm{QK}_{\mathrm{t}}$ & $(\mathrm{Bb})^{3 / 2} / \mathrm{QK}_{4}$ \\
\hline G.P. fulloize $/$ G.P. & 3.77 & 5.63 & 5.8 & 7.12 & 7.33 & 7.54 & 7.76 & 11.9 & 12.3 \\
\hline G.P. ·fullizer G.P. $P_{\text {type } 2}$ & 8.52 & 15.6 & 16 & 24.2 & 24.8 & 25.6 & 26.3 & 33.1 & 33.9 \\
\hline G.P.fullrizo $/ G . P_{\text {type } 3}$ & 4 & 2.8 & 2.8 & 8 & 8 & 8 & 8 & 5.7 & 5.7 \\
\hline G.P. fullsize $/ G . P_{\text {type } 4}$ & 8.9 & 13 & 14.6 & 23.7 & 26.5 & 22.3 & 24.9 & 22.3 & 24.9 \\
\hline
\end{tabular}

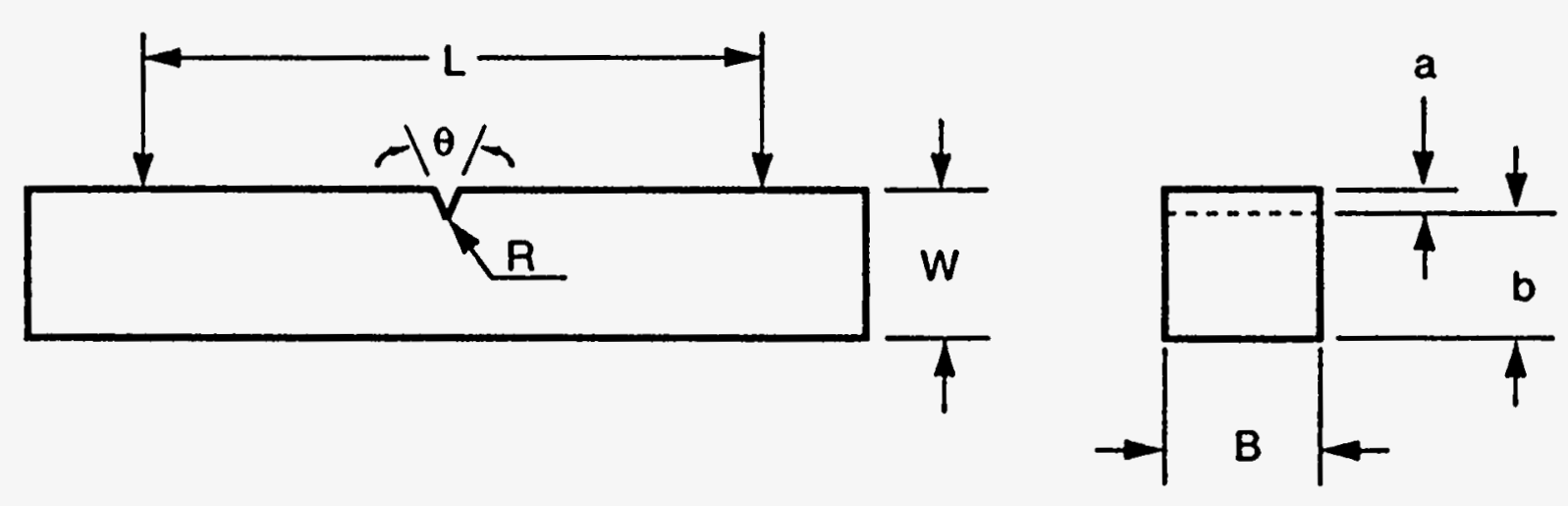

FIG.9--Definition of specimen dimensions. 
TABLE 3--Upper-shelf energies

\begin{tabular}{|c|c|c|c|c|c|c|c|c|c|}
\hline Material & $\begin{array}{l}\text { USE }_{\text {full intos }} \\
(J)\end{array}$ & $\begin{array}{l}\text { USE }_{\text {type } 1} \\
(J)\end{array}$ & $\frac{U^{U S E_{\text {ful nimo }}}}{\text { USE }_{\text {typo I }}}$ & $\begin{array}{l}\text { USE }_{\text {speo } 2} \\
(J)\end{array}$ & 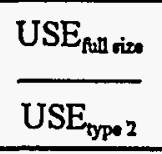 & $\begin{array}{l}\mathrm{USE}_{\text {typeo }} \\
(J)\end{array}$ & $\frac{\mathrm{USE}_{\text {ftul nixo }}}{\mathrm{USE}_{\text {type } 3}}$ & $\begin{array}{l}\text { USE }_{\text {tppe }} \\
(J)\end{array}$ & $\frac{U_{S E_{\text {pul aino }}}}{U_{S E_{\text {type }}}}$ \\
\hline $\begin{array}{l}\text { A } 533 \text { wide plate, } \mathrm{LT} \\
\text { orientation }\end{array}$ & 330 & 34.6 & 9.5 & 8.6 & 38.4 & 28.4 & 11.6 & 7.7 & 42.9 \\
\hline A 533 wide plate, TL orientation & 244 & 34.3 & 7.1 & 8.9 & 27.4 & 35.9 & 6.8 & 7.2 & 33.9 \\
\hline A 508 , as quenched & 115 & 21.6 & 5.3 & 6.1 & 18.9 & 17.6 & 6.5 & 5.5 & 20.9 \\
\hline $\begin{array}{l}\text { A } 508 \text {, quenced and tempered at } \\
599^{\circ} \mathrm{C}\end{array}$ & 102 & 21.1 & 4.8 & 5.3 & 19.2 & 15.0 & 6.8 & 5.1 & 20.0 \\
\hline $\begin{array}{l}\text { A } 508, \text { quenced and tempered at } \\
677^{\circ} \mathrm{C}\end{array}$ & 116 & 26.2 & 4.4 & 6.8 & 17.1 & 17.2 & 6.7 & 6.5 & 17.8 \\
\hline $\begin{array}{l}\text { A } 508 \text {, quenched and tempered } \\
\text { at } 704^{\circ} \mathrm{C}\end{array}$ & 164 & 37.3 & 4.4 & 9.3 & 17.6 & 24.6 & 6.7 & 7.5 & 21.9 \\
\hline $\begin{array}{l}\text { HSST Plate } 02, \text { TL orientation, } \\
\text { quarter thickness }\end{array}$ & 141 & 29.3 & 4.8 & 6.7 & 21.0 & 26.7 & 5.3 & 6.3 & 29.4 \\
\hline $\begin{array}{l}\text { HSST Plate } 02 \text {, TL orientation, } \\
\text { half thickness }\end{array}$ & 114 & & & & & 20.3 & 5.6 & & \\
\hline $\begin{array}{l}\text { HSST Plate } 014 \text {, quenched and } \\
\text { tempered at } 950^{\circ} \mathrm{C}\end{array}$ & 73 & 15.1 & 4.8 & 5.6 & 13.0 & 13.9 & 5.3 & 4.5 & 16.2 \\
\hline 15Kh2MFA, melt 103672 & 181 & 29.2 & 6.2 & 8.3 & 21.8 & 24.5 & 7.4 & 7.8 & 23.2 \\
\hline HSSI weld $72 W$ & 136 & 23.7 & 5.7 & 7.7 & 17.7 & 22.5 & 6.0 & 5.9 & 23.1 \\
\hline
\end{tabular}


Further investigations need to be performed to analyze these data. For the purposes of this study, analysis of USE data was limited to data below $200 \mathrm{~J}$ for full-size specimens.

Figures 10 through 13 present the correlation observed for the USE from full-size specimens to the USE from subsize specimen types 1 through 4 as well as ratios of $\mathrm{USE}_{\text {full size }}$ to $\mathrm{USE}_{\text {wubsize }}$ for each type of subsize specimen. Comparison of the ratios obtained with the normalization factors in Table 2 shows that no single factor can be considered as universal for any specimen geometry, although a normalization factor based on the fracture volume of specimens, namely $\left(\mathrm{Bb}^{2}\right)_{\text {full size }} /\left(\mathrm{Bb}^{2}\right)_{\text {mobsizer }}$, gives the closest estimation for each geometry, but these estimations are slightly higher than empirical ratios for each specimen geometry. An implementation of elastic or plastic stress concentration factors did not improve the correspondence. The results of this study indicate that it is preferable to use the obtained empirical ratios (see Figs. 10-13) as USE normalization factors for each specific geometry. The data do not show an obvious effect of the yield strength on the empirical ratios of USEs.

Since no single known existing correlation procedure would work for data from different subsize specimens, a new correlation was developed. It was assumed that the fracture process could be partitioned into low-energy brittle and high-energy ductile modes, and that different correlation procedures should be applied to each component of the fracture process. On the lower shelf, where fracture occurs by a low-energy cleavage mechanism, it is reasonable to assume a constant value of absorbed energy per unit of fracture surface area or:

$$
\left[\frac{\mathrm{LSE}}{\mathrm{Bb}}\right]_{\text {full size }}=\left[\frac{\mathrm{LSE}}{\mathrm{Bb}}\right]_{\text {subsize }},
$$

and thus

$$
\mathrm{LSE}_{\text {full size }}=\mathrm{NF}_{\text {britlle }} \times \mathrm{LSE}_{\text {subsize }} \text {, }
$$

where

$$
\mathrm{NF}_{\text {britle }}=\frac{(\mathrm{Bb})_{\text {full size }}}{(\mathrm{Bb})_{\text {subsize }}}
$$

In the transition region there is a competition between brittle and ductile fracture. It is assumed that the percent of shear on the fracture surface can be used as a measure of the amount of ductile fracture in the transition region. Based on these considerations, the following expression is proposed for normalizing the absorbed energy (E) of subsize specimens: 


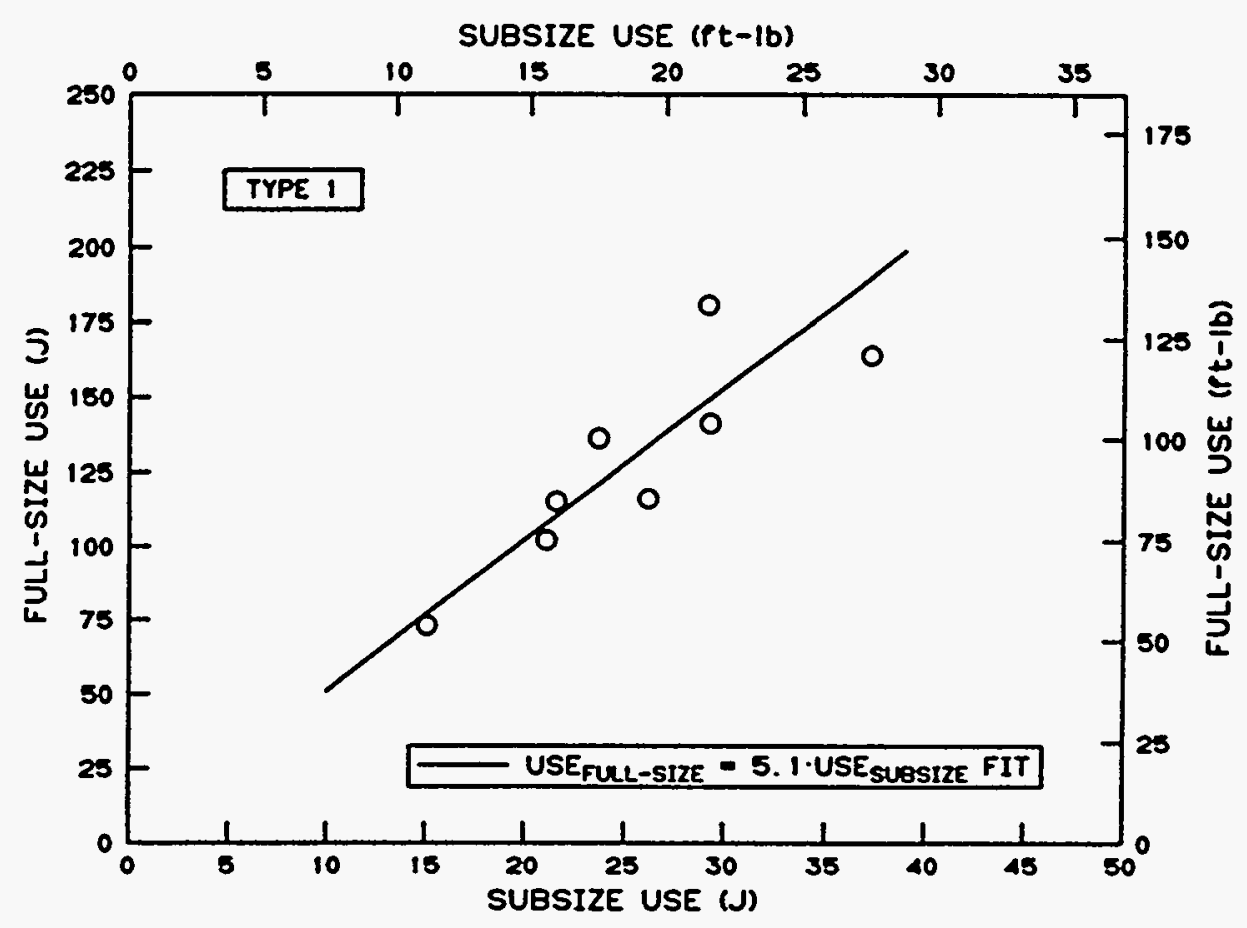

FIG. 10--Correlation of upper-shelf energies of full-size and type 1 subsize specimens.

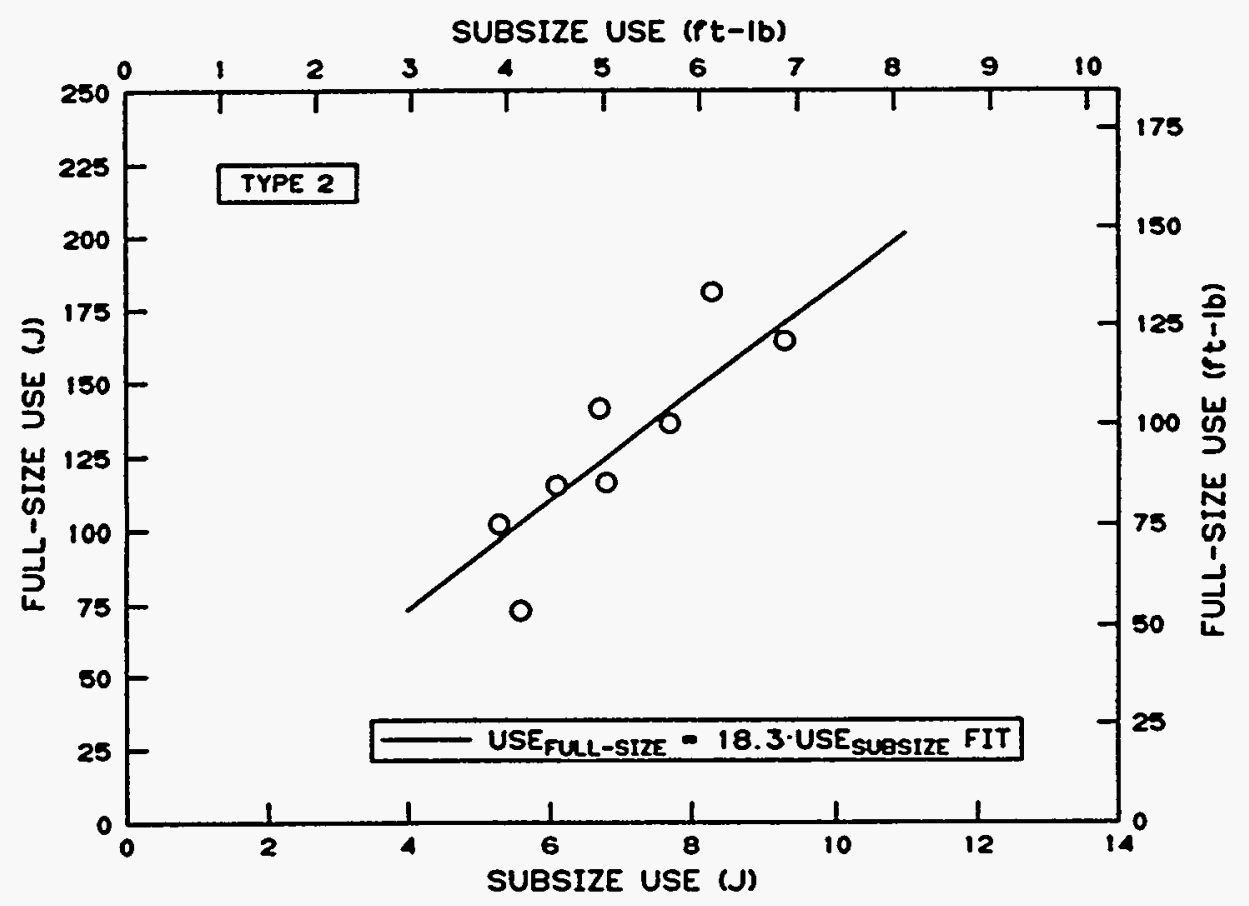

FIG. 11--Correlation of upper-shelf energies of full-size and type 2 subsize specimens. 


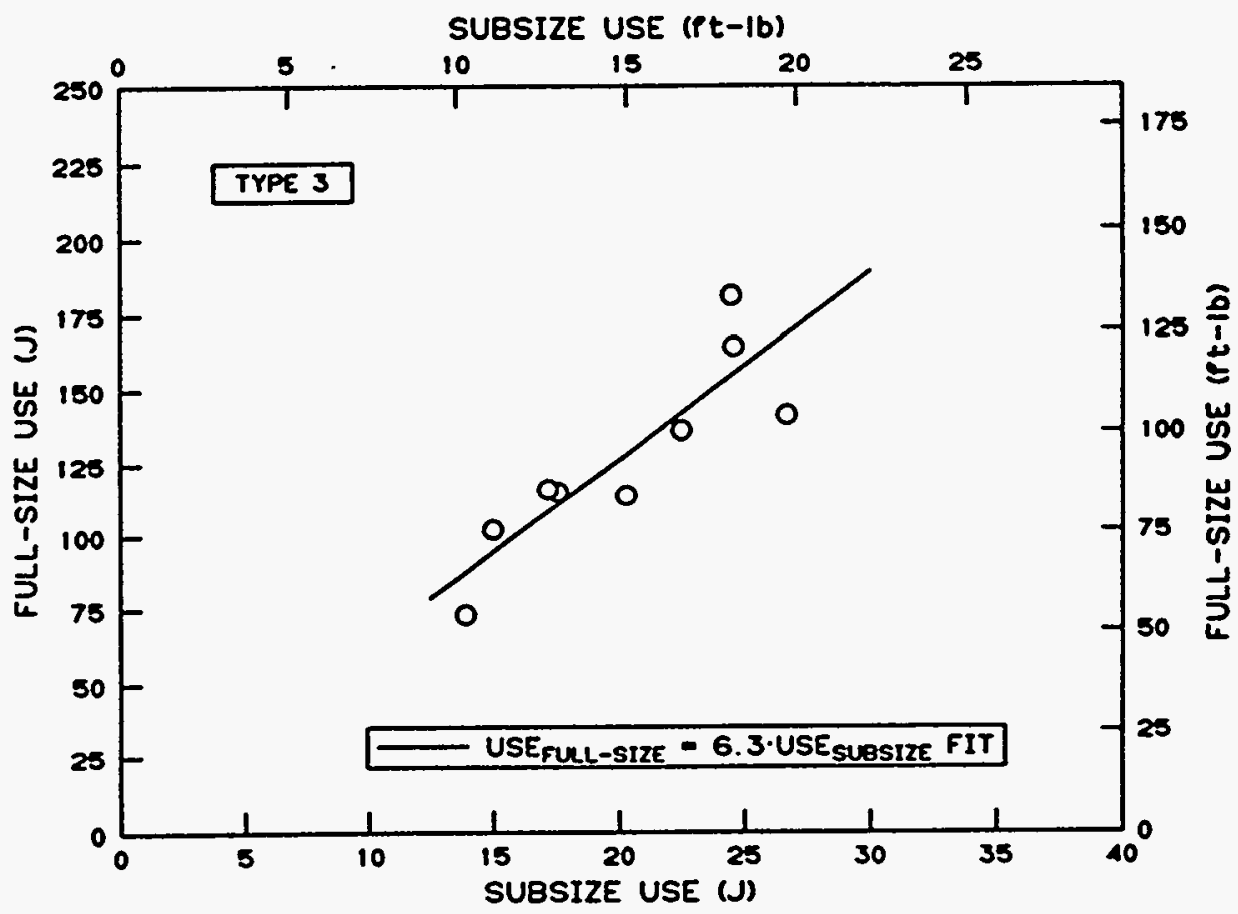

FIG. 12--Correlation of upper-shelf energies of full-size and type 3 subsize specimens.

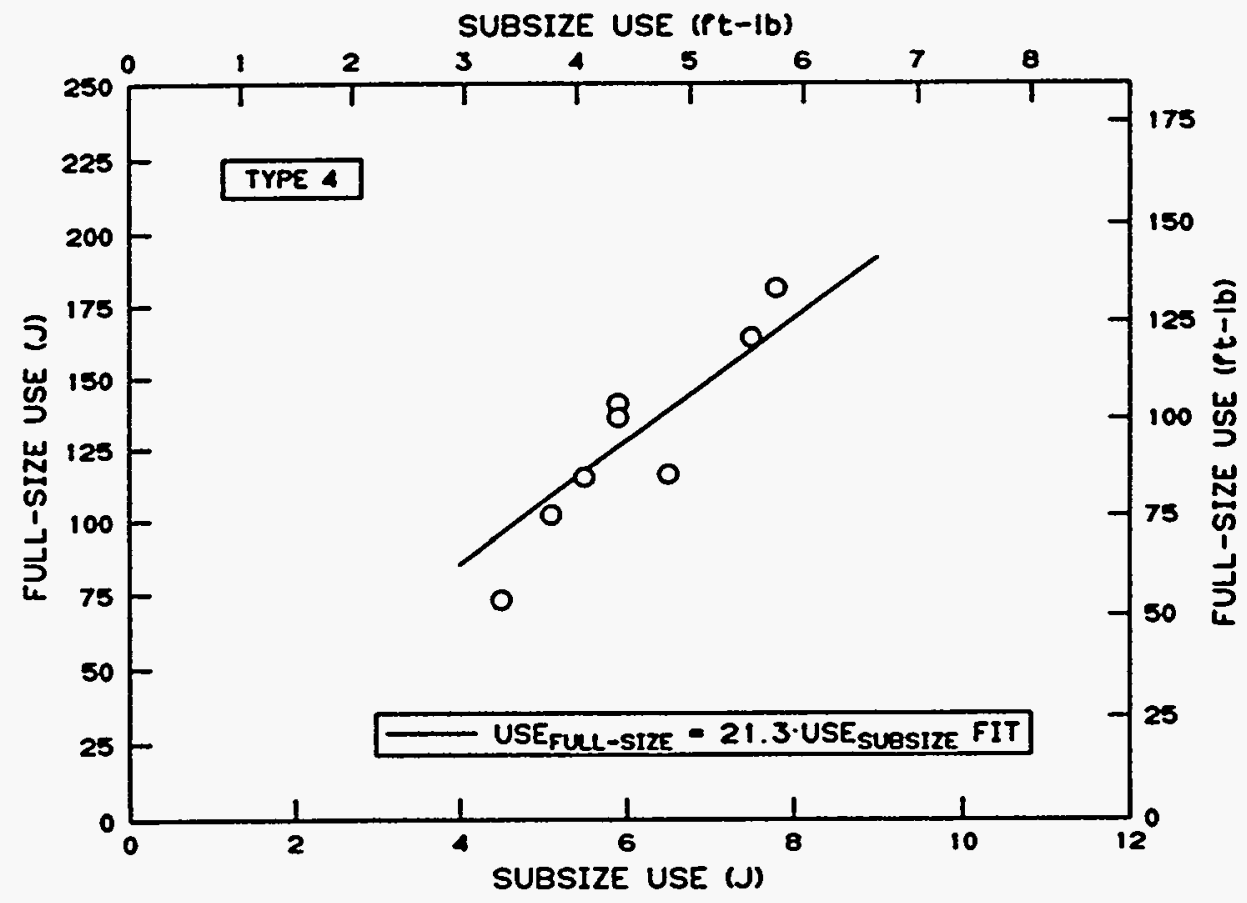

FIG. 13--Correlation of upper-shelf energies of full-size and type 4 subsize specimens. 


$$
E=E_{\text {subsize }} \times\left[\mathrm{NF}_{\text {britle }} \frac{100-\text { SHEAR }}{100}+\mathrm{NF}_{\text {ductile }} \frac{\text { SHEAR }}{100}\right] \text {, }
$$

where $\mathrm{NF}_{\text {briule }}$ is a normalization factor for the brittle mode of fracture [Eq. (10)] and is equal to $3.77,8.52,4.00$, and 8.90 for types $1,2,3$, and 4 subsize specimens, respectively. $\mathrm{NF}_{\text {ductile }}$ is a normalization factor for the ductile mode and is equal to 5.1, $18.3,6.3$, and 21.3 for types 1, 2, 3, and 4 subsize specimens, respectively (see Figs. 10 through 13). SHEAR is the percent of shear fracture on the fracture surface measured, in general, visually. Visual determination of the percent of shear fracture requires an interpretation of the appearance of the fracture surface, a process that is subjective and may vary from person to person. This variability may lead to some uncertainty in values of the transition temperature determined with the normalization process in Eq. (11). To estimate how serious a problem this might be, data from HSST Plate 02 type 3 specimens were examined. The original data were normalized and analyzed to determine the transition temperatures at energy levels of 41 and $68 \mathrm{~J}\left(T_{41 \mathrm{~J}}\right.$ and $T_{68 \mathrm{~J}}$, respectively). Then the percent shear data were modified, first by adding $10 \%$ to each data point, and then by subtracting $10 \%$ from each data point. The lower- and upper-shelf levels were kept at 0 and $100 \%$, respectively, in both cases. The energy levels from the subsize specimens were then normalized with the altered shear values, in both cases. The results of these changes in the shear values are shown in Table 4 . Changing of the shear values by $\pm 10 \%$ results in very small changes in the transition temperatures, showing that the normalization procedure is not overly sensitive to changes in the measured value of percent shear.

\section{CORRELATION OF TRANSITION TEMPERATURE OF FULL-SIZE AND SUBSIZE SPECIMENS}

The effect of specimen size on the DBTT can be explained as suggested by Davidenkov [33]. The yield stress $\left(\sigma_{y}\right)$ depends on temperature, increasing as the temperature decreases, while the cleavage fracture stress $\left(\sigma_{f}\right)$ is assumed to be temperature independent (see Fig. 14). The intersection of these curves determines the ductile-to-brittle transition. The size effect can be explained by a statistical theory of strength, whose mathematical interpretation was given by Weibull [34]. It is based on the assumption that brittle failure is determined by the value of the local stress in the piece at the point where the most critical structural defect is located. Using the theory of probability, Weibull established the dependence of the brittle strength on the volume of the specimen. For the same states of stress but various dimensions of the specimens, the brittle fracture stress changes as $V^{-1 / m}$, where $V$ is the volume of the specimen and $m$ is a constant of the material. The scatter obtained will be larger for smaller specimens. The dependence of brittle fracture on the volume of specimens for different types of tests has been experimentally confirmed $[35,36]$. 
TABLE 4--Effects of changes in percent shear on values of transition temperatures at 41 and $68 \mathrm{~J}$ for normalized data from type 3 specimens of HSST Plate 02

\begin{tabular}{|c|c|c|c|}
\hline & \multicolumn{3}{|c|}{$\begin{array}{l}\text { Transition temperature } \\
\left({ }^{\circ} \mathrm{C}\right)\end{array}$} \\
\hline & $\begin{array}{l}\text { As-measured } \\
\text { shear }\end{array}$ & $\begin{array}{l}\text { As-measured } \\
+10 \%\end{array}$ & $\begin{array}{l}\text { As-measured } \\
-10 \%^{\circ}\end{array}$ \\
\hline $\mathrm{T}_{4 \mathrm{IJ}}$ & -28 & -30 & -26 \\
\hline$T_{68 \mathrm{~J}}$ & -2 & -5 & 1 \\
\hline
\end{tabular}

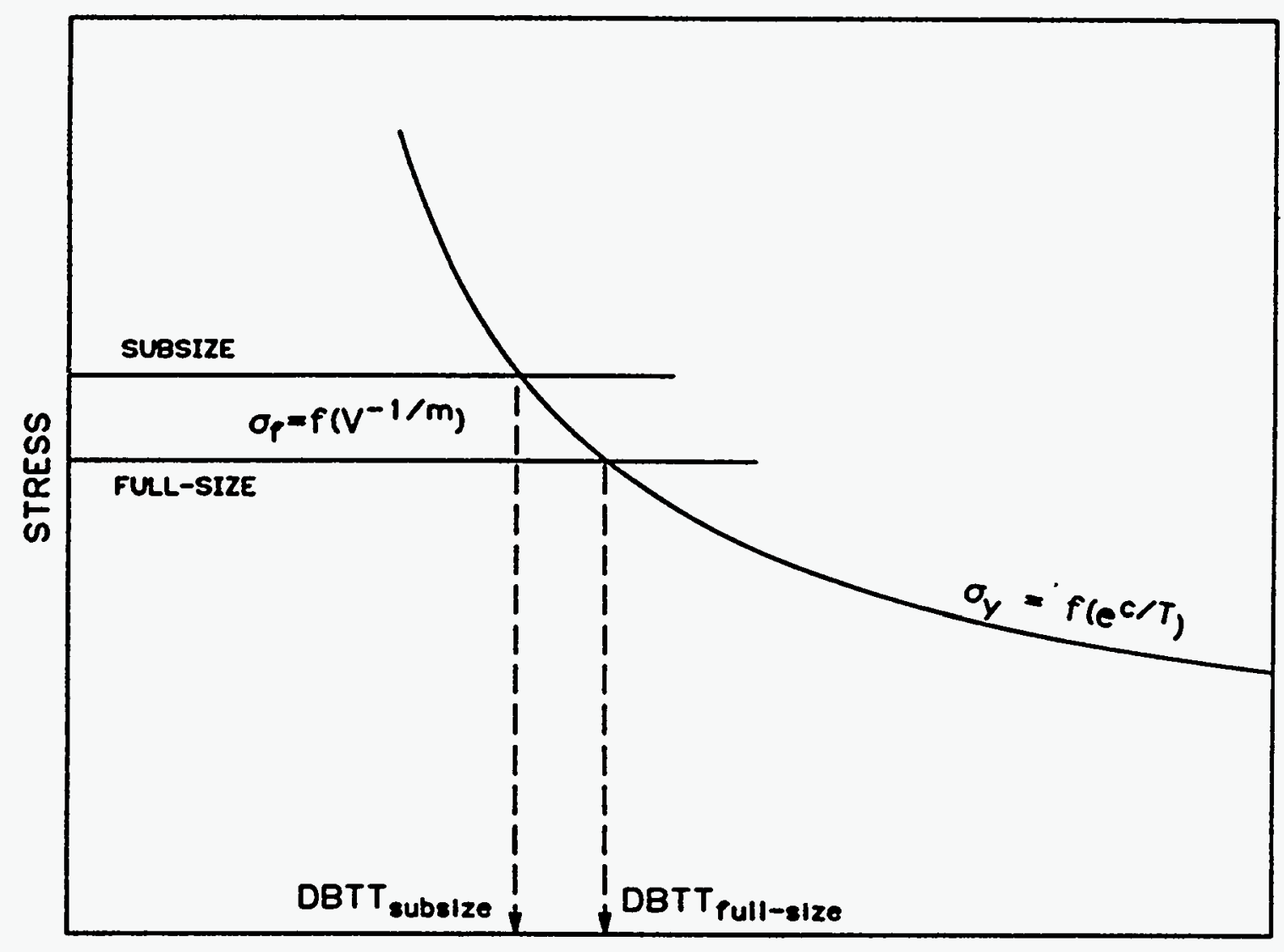

TEMPERATURE

FIG. 14--Stress-temperature diagram showing the effect of specimen size on transition temperature. 
The above discussion is illustrated in Fig. 14. The dependence of yield stress on temperature can be expressed as:

$$
\sigma_{y}=A e^{c / T}
$$

where $\mathrm{A}$ and $\mathrm{c}$ are constants and $\mathrm{T}$ is temperature in $\mathrm{K}$. According to Weibull, the dependence of the brittle fracture stress on volume is:

$$
\sigma_{\mathrm{f}}=\mathrm{ZV}^{-1 / \mathrm{m}}
$$

where $\mathrm{Z}$ and $\mathrm{m}$ are constants. If we define the DBTT as the temperature at which $\sigma_{\mathrm{y}}$ is raised so that it equals $\sigma_{f}$ (see Fig. 14), then:

$$
A e^{\frac{c}{D B T T}}=Z V^{-1 / m}
$$

Taking the natural logarithm of Eq. (14) results in:

$$
\operatorname{DBTT}=\frac{1}{R-S \ln V},
$$

where $\mathrm{R}$ and $\mathrm{S}$ are constants.

Thus, Eq. (15) describes, in general, the shift of DBTT to lower temperatures due to a reduction in size. However, different notch geometries result in different stress distributions under the notch for different subsize specimens, which does not allow the use of Eq. (16) for a quantitative account of size effects in notched impact tests. Nevertheless, it suggests the establishment of an empirical correlation:

$$
\operatorname{DBTT}_{\text {full size }}=\operatorname{DBTT}_{\text {subsize }}+M
$$

where $\mathrm{DBTT}_{\text {full size }}$ and DBTT ${ }_{\text {subsize }}$ are transition temperatures for full-size and subsize specimens, respectively, and $M$ is a shift of DBTT due to specimen size. A similar approach has been used in Refs. [6,11,19].

The following procedure was used to determine the temperature correction $\mathrm{M}$. Absorbed energy values from subsize specimens were normalized by Eq. (11). These data 
were then fit with a hyperbolic tangent function [Eq. (1)] to determine temperatures at $41 \mathrm{~J}$ $\left(\mathrm{T}_{41 \mathrm{~J}}\right), 68 \mathrm{~J}\left(\mathrm{~T}_{68 \mathrm{~J}}\right)$, and at the middle of the transition zone $\left(\mathrm{T}_{\mathrm{MT}}\right)$. Figures 15 through 18 summarize the comparison of transition temperatures for full-size and different subsize specimens. Transition temperatures at $50 \%$ shear $\left(\mathrm{T}_{50 x}\right)$ were also included in the analysis. The data show a linear correspondence of transition temperatures. The following equations were obtained for the different subsize specimens:

$$
\begin{aligned}
& \mathrm{DBTT}_{\text {full size }}=\mathrm{DBTT}_{\text {type 1 }}+30( \pm 28){ }^{\circ} \mathrm{C} ; \\
& \mathrm{DBTT}_{\text {full size }}=\mathrm{DBTT}_{\text {type 2 }}+53( \pm 24){ }^{\circ} \mathrm{C} ; \\
& \mathrm{DBTT}_{\text {full size }}=\mathrm{DBTT}_{\text {type } 3}+34( \pm 20){ }^{\circ} \mathrm{C} ; \\
& \mathrm{DBTT}_{\text {full size }}=\mathrm{DBTT}_{\text {type 4 }}+38( \pm 30){ }^{\circ} \mathrm{C} ;
\end{aligned}
$$

where the numbers in parentheses are $\pm 2 \sigma$ intervals.

Figure 19 shows the dependence of the temperature-size correction, $\mathrm{M}$, taken from Eqs. (17) through (20), on the nominal fracture volume, $\mathrm{Bb}^{2}$, for the subsize specimens used in this work. The solid line is a fit to the data:

$$
\mathrm{M}=98-15.1 \times \ln \left(\mathrm{Bb}^{2}\right) .
$$

The form of this fit is suggested by Eq. (15), and the equation was forced to give a correction factor of 0 for the full-size specimen. The trend agrees, in general, with the scheme for the effects of specimen size on the DBTT based on the statistical theory of strength (Fig. 14). Deviations from this dependence reflect the constraint effects of different notch dimensions, but the form of the dependence may be used as guidance to estimate size corrections for subsize specimens. Other investigators, i.e., [16], are considering the use of side-grooving to improve the DBTT shift correlations.

Figure 20 illustrates the normalization procedure described above with the data from HSSI weld $72 \mathrm{~W}$. The absorbed energies for subsize specimens were normalized by Eq. (11). Test temperatures were then shifted forward to size adjustment values from Eq. (17) through (20) for the corresponding subsize specimens. Data from subsize specimens normalized by this procedure correspond very well with the mean and $95 \%$ confidence intervals from full-size specimens, as Fig. 20 shows. 


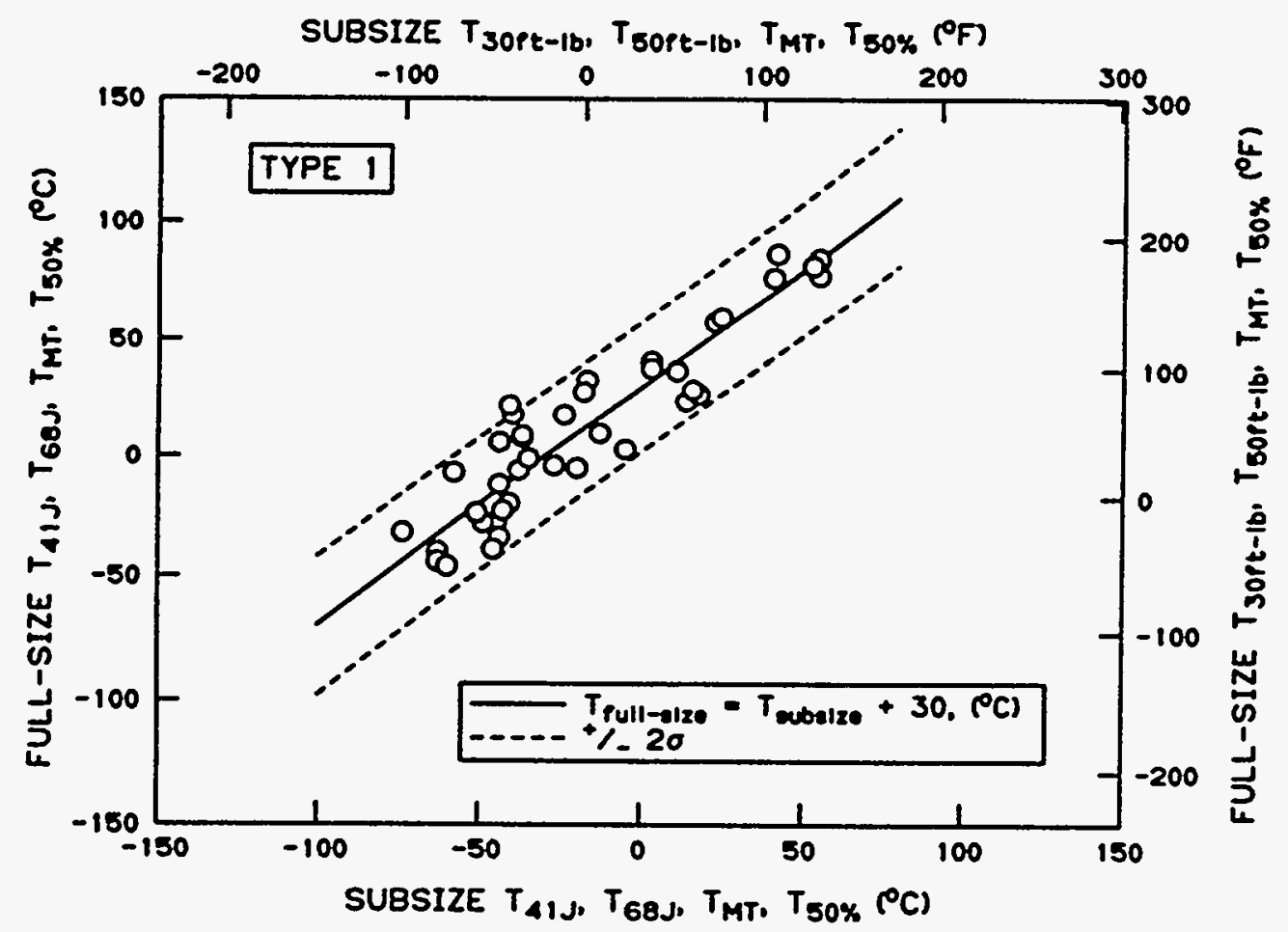

FIG. 15--Correlation of transition temperatures determined from data from full-size specimens and normalized data for type 1 subsize specimens.

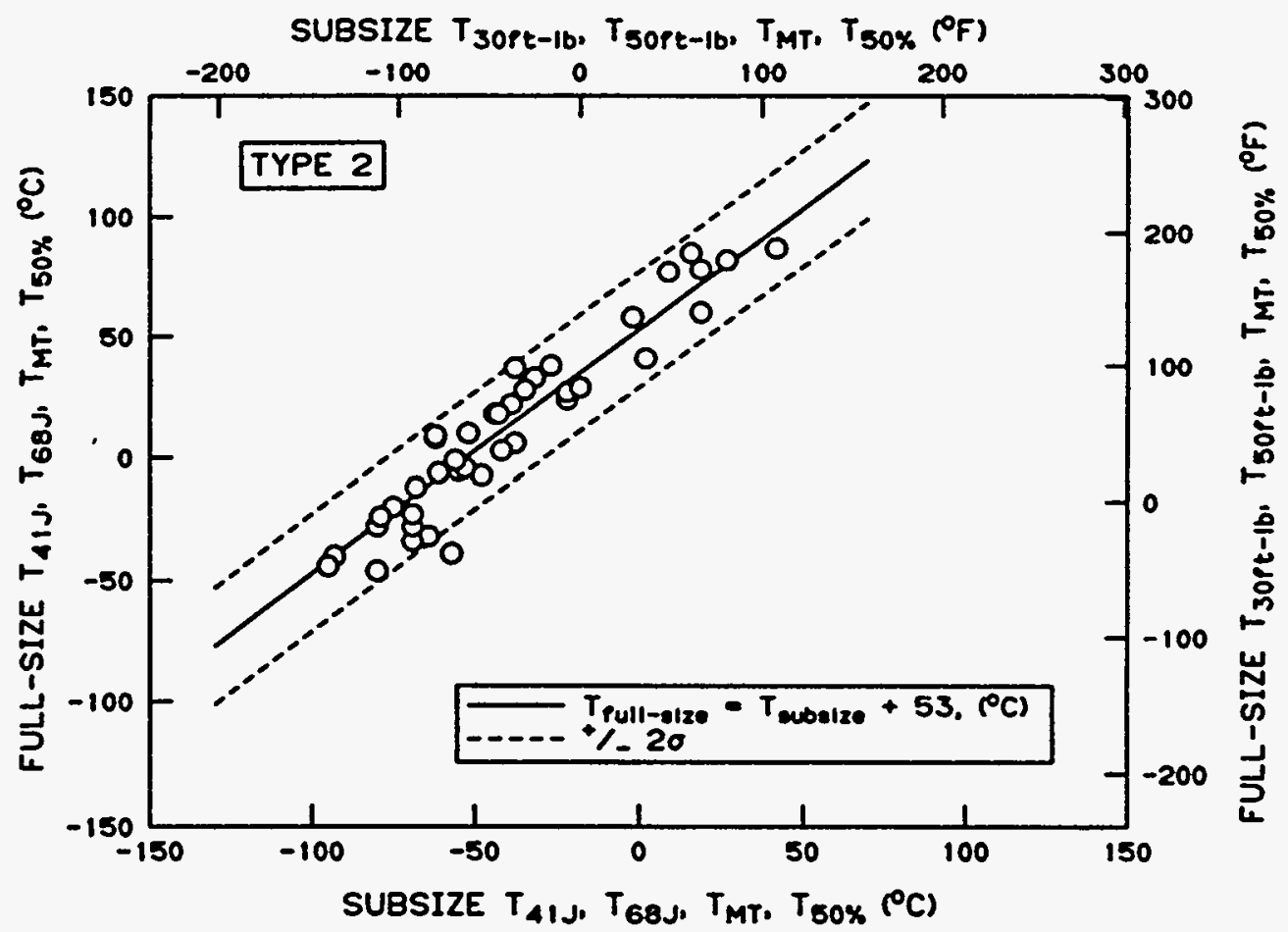

FIG. 16--Correlation of transition temperatures determined from data from full-size specimens and normalized data for type 2 subsize specimens. 


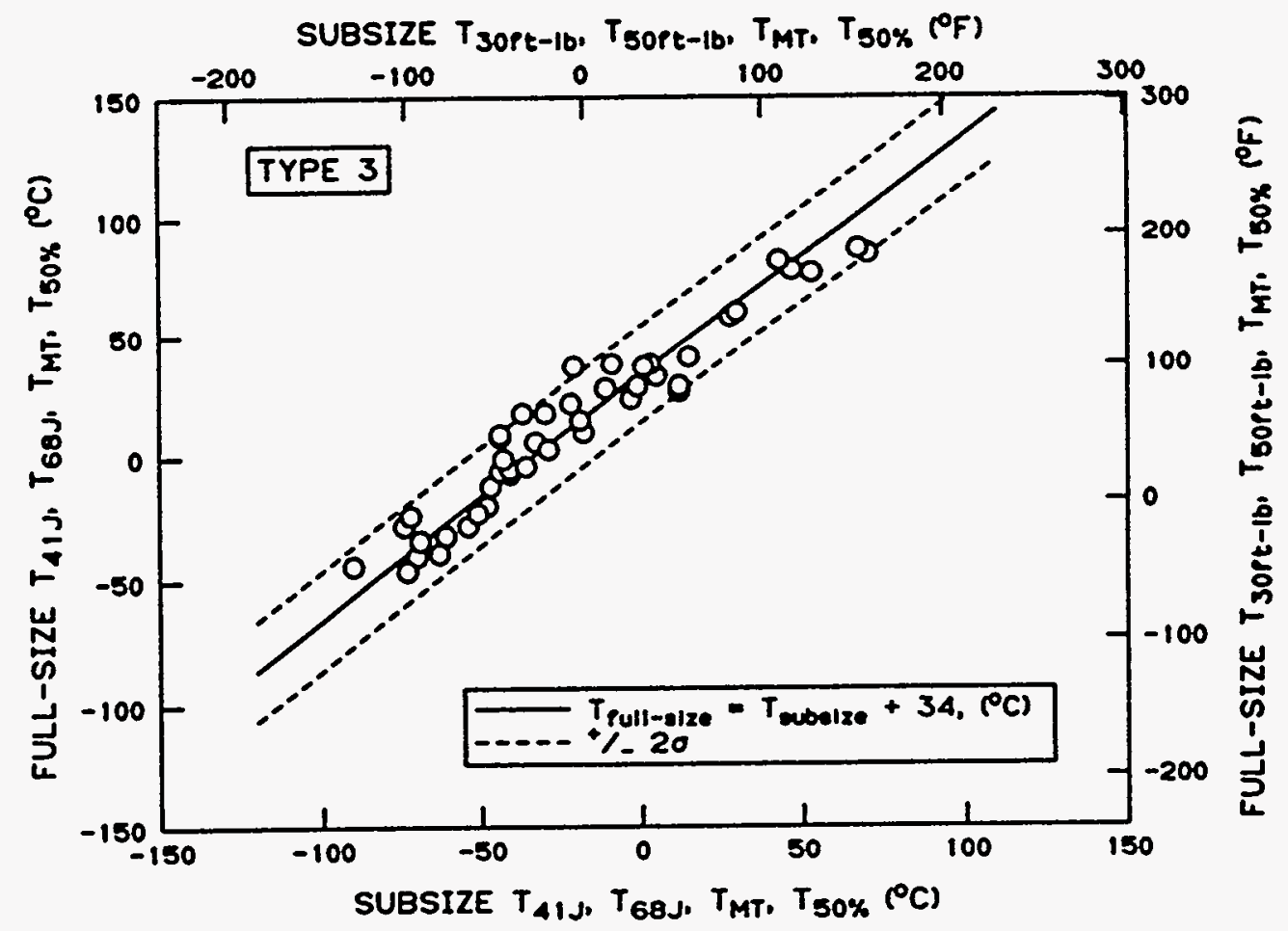

FIG. 17--Correlation of transition temperatures determined from data from full-size specimens and normalized data for type 3 subsize specimens.

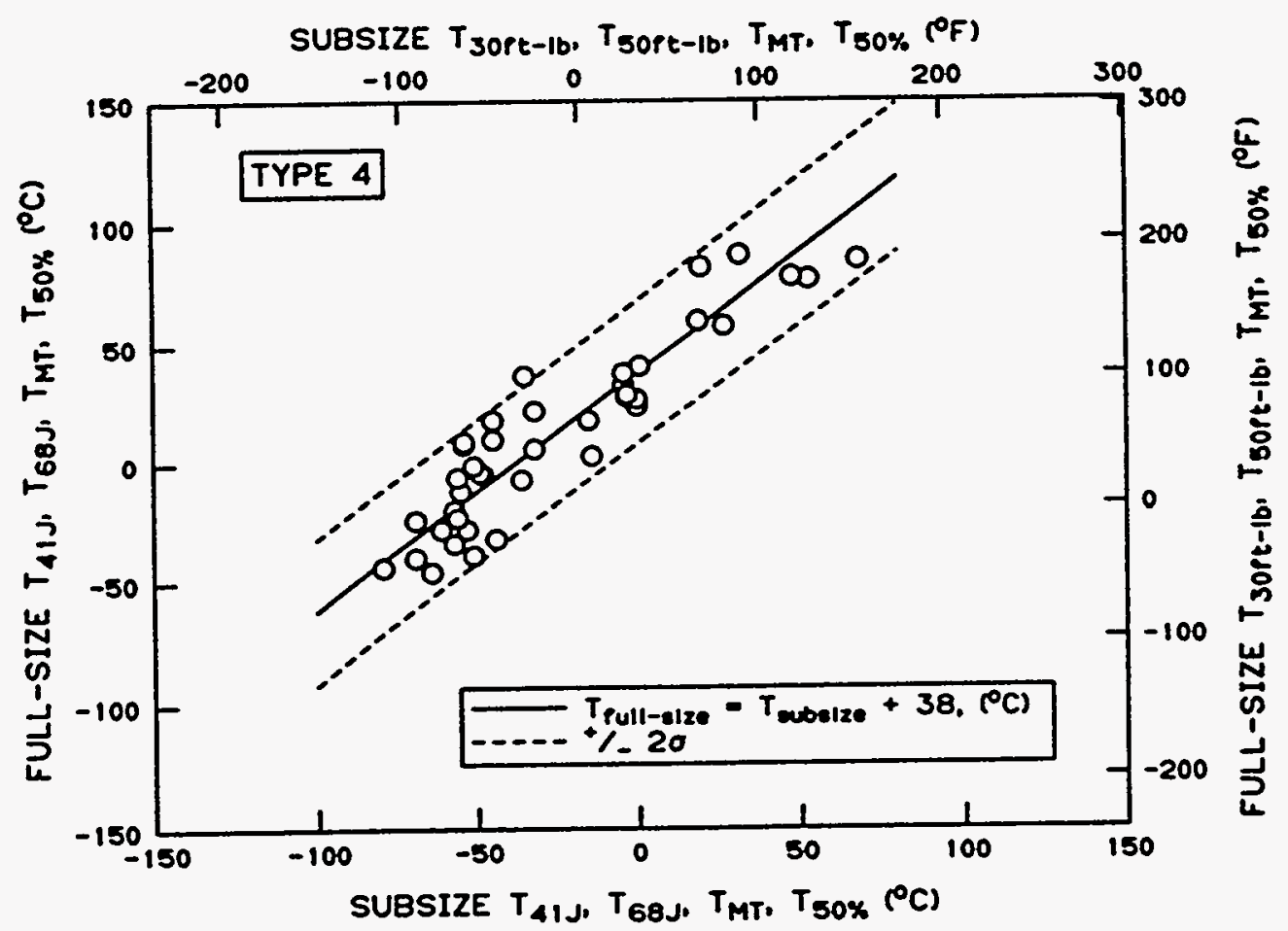

FIG. 18--Correlation of transition temperatures determined from data from full-size specimens and normalized data for type 4 subsize specimens. 
Examination of the standard deviations reported for Eqs. (17) through (20) shows that the type 3 specimen has the smallest value, suggesting that this specimen is the best of the four types examined for determining the DBTT, since it results in the smallest error. It was also noted that this specimen was more likely to fracture completely when tested in the uppershelf regime, whereas the other subsize specimens tended to wrap around the tup rather than fracture in this regime. This failure to fracture on the upper shelf is exacerbated with high upper-shelf materials, and accounts for the poor agreement found for materials with uppershelf levels over $200 \mathrm{~J}$, as measured with full-size specimens. The type 1 and 2 subsize specimens have relatively short notch depth to specimen width ratios $(\mathrm{a} / \mathrm{W})$ of 0.16 and 0.15 , respectively. The type 3 specimen has a relatively deeper notch, with $\mathrm{a} / \mathrm{W}=0.2$. This relatively deeper notch will encourage fracture on the upper shelf. The type 4 specimen has a value of a/W of 0.25 , but the specimen thickness is only $3 \mathrm{~mm}$ as compared to $5 \mathrm{~mm}$ for type 3. The greater thickness of the type 3 specimen will increase the transverse constraint developed in this specimen as compared to the thinner type 4 specimen, and again encourage fracture. Thus, of all the specimens tested, the type 3 specimen seems to be the best, although it is the largest of the subsize specimens.

\section{SUMMARY AND CONCLUSIONS}

Five types of subsize specimens from ten materials were studied in the present work. The main results are as follows:

1. Subsize Charpy specimens may be useful for studies when material availability is limited. The broken halves of surveillance specimens can be remachined into subsize specimens to extend current surveillance programs and monitor annealing response. The smallest specimen recommended by ASTM E $23(5 \times 5 \times 55 \mathrm{~mm})$ is too long for such an application without resorting to reconstitution techniques.

2. It was found that (a) an increase in the notch depth decreases the USE, but has little effect on the DBTT; (b) a decrease of the notch root radius reduces the USE and increases the DBTT; (c) variation of notch angle from 30 to $45^{\circ}$ while keeping the remaining dimensions identical does not result in any effect on transition temperature or USE, and (d) span and impact velocity (in the ranges studied) do not affect the USE and DBTT.

3. The following equation is proposed for normalizing impact energy values from subsize Charpy specimens:

$$
\mathrm{E}=\mathrm{E}_{\text {subsize }} \times\left[\mathrm{NF}_{\text {britle }} \frac{100-\text { SHEAR }}{100}+\mathrm{NF}_{\text {ductile }} \frac{\text { SHEAR }}{100}\right] \text {, }
$$


where $\mathrm{NF}_{\text {britle }}$ is a normalization factor equal to the ratio of the fracture surface of the full-size specimen to the fracture surface of the corresponding subsize specimen; $\mathrm{NF}_{\text {ductile }}$ is an empirical normalization factor equal to $5.1,18.3,6.3$, and 21.3 for types $1,2,3$, and 4 subsize specimens, respectively, and SHEAR is the percent of shear fracture on the fracture surface.

4. The empirical correlations between the DBTT of full-size and the different subsize specimens were determined as follows:

$$
\begin{aligned}
& \operatorname{DBTT}_{\text {full size }}=\mathrm{DBTT}_{\text {type 1 }}+30( \pm 28){ }^{\circ} \mathrm{C} ; \\
& \mathrm{DBTT}_{\text {full size }}=\mathrm{DBTT}_{\text {type 2 }}+53( \pm 24){ }^{\circ} \mathrm{C} ; \\
& \mathrm{DBTT}_{\text {full size }}=\mathrm{DBTT}_{\text {type } 3}+34( \pm 20){ }^{\circ} \mathrm{C} ; \\
& \mathrm{DBTT}_{\text {full size }}=\mathrm{DBTT}_{\text {type 4 }}+38( \pm 30){ }^{\circ} \mathrm{C} ;
\end{aligned}
$$

where the numbers in parentheses are $\pm 2 \sigma$ intervals. Further understanding of the shift in the DBTT as a function of specimen size needs to be pursued.

5. Results obtained from the subsize specimens as well as the empirical correlations can be used for development of an ASTM standard practice for impact testing of subsize specimens for supplementary surveillance data in nuclear applications.

\section{ACKNOWLEDGMENTS}

This research was sponsored by the Office of Nuclear Regulatory Research, U.S. Nuclear Regulatory Commission under Interagency Agreement DOE 1886-8109-8L with the U.S. Department of Energy under contract DE-AC05-84OR21400 with Lockheed Martin Energy Systems. The authors would like to acknowledge the programmatic support of the Heavy-Section Steel Irradiation Program at ORNL. We appreciate the useful discussions of results and the helpful review of the manuscript by David J. Alexander. The impact tests were conducted by Eric T. Manneschmidt and the technical manuscript was prepared by Julia L. Bishop. This research was also supported in part by an appointment to the ORNL Postdoctoral Research Program administered by the Oak Ridge Institute for Science and Education. 


\section{REFERENCES}

[1] A. D. Amayev, A. M. Kryukov, and M. A. Sokolov, "Recovery of the Transition Temperature of Irradiated WWER-440 Vessel Metal by Annealing," pp. 369-79 in Radiation Embrittlement of Nuclear Reactor Pressure Vessel Steels: An International Review (Fourth Volume), ASTM STP 1170, L. E. Steele, Ed., American Society for Testing and Materials, Philadelphia, 1993.

[2] A. M. Kryukov and M. A. Sokolov, "Investigation of Material Behavior Under Reirradiation after Annealing Using Subsize Specimens," pp. 417-23 in Small Specimen Test Techniques Applied to Nuclear Reactor Vessel Thermal Annealing and Plant Life Extension, ASTM STP 1204, W. R.Corwin, F. M.Haggag, and W. L.Server, Eds., American Society for Testing and Materials, Philadelphia, 1993.

[3] W. L. Server, "Review of In-Service Thermal Annealing of Nuclear Reactor Pressure Vessels,"pp. 979-1008 in Effects of Radiation on Materials: Twelfth International Symposium, ASTM STP 870, F. A. Garner and J. S. Perrin, Eds., American Society for Testing and Materials, Philadelphia, 1985.

[4] Proceedings of the DOE/SNL/EPRI-Sponsored Reactor Pressure Vessel Thermal Annealing Workshop, February 17-18, 1994, Albuquerque, New Mexico, SAND 94-1515, 1994.

[5] R. Ahlstrand, E. N. Klausnitzer, D. Lange, C. Leitz, D. Pastor, and M. Valo, "Evaluation of the Recovery Annealing of the Reactor Pressure Vessel of NPP Nord (Greifswald) Units 1 and 2 by Means of Subsize Impact Specimens," pp. 312-43 in Radiation Embrittlement of Nuclear Reactor Pressure Vessel Steels: An International Review (Fourth Volume), ASTM STP 1170, L. E. Steele, Ed., American Society for Testing and Materials, Philadelphia, 1993.

[6] A. D. Amayev, V. I. Badanin, A. M. Kryukov, V. A. Nikolayev, M. F. Rogov, and M. A. Sokolov, "Use of Subsize Specimens for Determination of Radiation Embrittlement of Operating Reactor Pressure Vessels," pp. 424-39 in Small Specimen Test Techniques Applied to Nuclear Reactor Vessel Thermal Annealing and Plant Life Extension, ASTM STP 1204, W. R. Corwin, F. M. Haggag, and W. L. Server, Eds., American Society for Testing and Materials, Philadelphia, 1993.

[7] Standard Test Method for Notched Bar Impact Testing of Metallic Materials, ASTM E 23-93a, American Society for Testing and Materials, Philadelphia, 1993.

[8] M. Grounes, "Review of Swedish Work on Irradiation Effects in Pressure Vessel Steels and on Significance of Data Obtained," pp. 224-59 in Effects of Radiation on Structural Metals, ASTM STP 426, American Society for Testing and Materials, Philadelphia, 1967.

[9] C. Curll, "Subsize Charpy Correlation with Standard Charpy," Materials Research \& Standards, 91-94 (February 1961).

[10] R. C. McNicol, "Correlation of Charpy Test Results for Standard and Nonstandard Size Specimens," Welding Research Supplement, 385-93 (September 1965).

[11] E. Klausnitzer, H. Kristof, and R. Leistner, "Assessment of Toughness Behavior of Low Alloy Steels by Subsize Impact Specimens," pp. 3-37 in Transactions of the 8th International Conference on Structural Mechanics in Reactor Technology, Brussels, 
August 1985, Vol G, International Association for Structural Mechanics in Reactor Technology, 1986.

[12] W. R. Corwin and A. M. Hougland, "Effect of Specimen Size and Material Condition on the Charpy Impact Properties of 9Cr-1Mo-V-Nb Steel," pp. 325-38 in The Use of Small-Scale Specimens for Testing Irradiated Material, ASTM STP 888, W. R. Corwin and G. E. Lucas, Eds., American Society for Testing and Materials, Philadelphia, 1986.

[13] G. E. Lucas, G. R. Odette, J. W. Sheckherd, P. McConnell, and J. Perrin, "Subsized Bend and Charpy V-Notch Specimens for Irradiated Testing," pp. 304-24 in The Use of Small-Scale Specimens for Testing Irradiated Material, ASTM STP 888, W. R. Corwin and G. E. Lucas, Eds., American Society for Testing and Materials, Philadelphia, 1986.

[14] H. Kayano, H. Kurishita, A. Kimura, M. Narui, M. Yamazaki, and Y. Suzuki, "Charpy Impact Testing Using Miniature Specimens and Its Application to the Study of Irradiation Behavior of Low-Activation Ferritic Steels," J. Nucl. Mater. 179-181, 425-88 (1991).

[15] H. Kurishita, H. Kayano, M. Narui, M. Yamazaki, Y. Kano, and I. Shibahara, "Effects of V-Notch Dimensions on Charpy Impact Test Results for Differently Sized Miniature Specimens of Ferritic Steel," Mater. Trans., JIM, 34(11), 1042-52 (1993).

[16] M. P. Manahan and C. Charles, "A Generalized Methodology for Obtaining Quantitative Charpy Data from Test Specimens of Nonstandard Dimensions," Nucl. Technol. 90, 245-59 (May 1990).

[17] M. P. Manahan, "Determination of Charpy Transition Temperature of Ferritic Steels Using Miniaturized Specimens," J. Mater. Sci. 25, 3429-38 (1990).

[18] R. K. Nanstad, D. E. McCabe, R. L. Swain, and M. K. Miller, Martin Marietta Energy Systems, Inc., Oak Ridge Natl. Lab., Chemical Composition and $R T_{N D T}$ Determinations for Midland Weld WF-70, USNRC Report NUREG/CR-5914 (ORNL-6740), December 1992.

[19] D. J. Alexander and R. L. Klueh, "Specimen Size Effects in Charpy Impact Testing," pp. 179-91 in Charpy Impact Test: Factors and Variables, ASTM STP 1072, J. M. Holt, Ed., American Society for Testing and Materials, Philadelphia, 1990.

[20] A. S. Kumar, F. A. Garner, and M. L. Hamilton, "Effect of Specimen Size on the Upper Shelf Energy of Ferritic Steels," pp. 487-95 in Effects of Radiation on Materials: 14th International Symposium (Volume II), ASTM STP 1046, N. H. Packan, R. E. Stoller, and A. S. Kumar, Eds., American Society for Testing and Materials, Philadelphia, 1990.

[21] B. S. Louden, A. S. Kumar, F. A. Garner, M. L. Hamilton, and W. L. Hu, "The Influence of Specimen Size on Charpy Impact Testing of Unirradiated HT-9," J. Nucl. Mater. 155-157. 662-67 (1988).

[22] A. S. Kumar, B. S. Louden, F. A. Garner, and M. L. Hamilton, "Recent Improvements in Size Effects Correlations for DBTT and Upper Shelf Energy of Ferritic Steels," pp. 47-61 in Small Specimen Test Techniques Applied to Nuclear Reactor Vessel Thermal Annealing and Plant Life Extension, ASTM STP 1204, W. R. Corwin, F. M. Haggag, and W. L. Server, Eds., American Society for Testing and Materials, Philadelphia, 1993. 
[23] W. R. Corwin, R. L. Klueh, and J. M. Vitek, "Effect of Specimen Size and Nickel Content on the Impact Properties of $12 \mathrm{Cr}-1 \mathrm{MoVW}$ Ferritic Steel," J. Nucl. Mater. 22-123, 343-48 (1984).

[24] F. Abe, T. Noda, H. Araki, M. Okada, M. Narui, and H. Kayano, "Effect of Specimen Size on the Ductile-Brittle Transition Behavior and the Fracture Sequence of $9 \mathrm{Cr}-\mathrm{W}$ Steels," J. Nucl. Mater. 150, 292-301 (1987).*

[25] E. N. Klausnitzer and G. Hofmann, "Reconstituted Impact Specimens with Small Inserts," pp. 76-90 in Effects of Radiation on Materials: 15th International Symposium, ASTM STP 1125, R. E. Stoller, A. S. Kumar, and D. S. Gelles, Eds., American Society for Testing and Materials, Philadelphia, 1992.

[26] N. H. Fahey, "Effects of Variables in Charpy Impact Testing," Materials Research \& Standards 1, 872-76 (November 1961).

[27] G. E. Lucas, G. R. Odette, J. W. Sheckherd, and M. R. Krishnadev, "Recent Progress in Subsized Charpy Impact Specimen Testing for Fusion Reactor Materials Development," pp. 728-33 in Fusion Technology, Vol. 10, November 1986.

[28] A. S. Kumar, S. T. Rosinski, N. S. Cannon, and M. L. Hamilton, "Subsize Specimen Testing of a Nuclear Reactor Pressure Vessel Material," pp. 147-55 in Effects of Radiation on Materials: 16th International Symposium, ASTM STP 1175, A. S. Kumar, D. S. Gelles, R. K. Nanstad, and E. A. Little, Eds., American Society for Testing and Materials, Philadelphia, 1993.

[29] H. Neuber, Theory of Notch Stresses, Springer, Berlin, 1958.

[30] R. Sandstrom and Y. Bergstrom, "Relationship Between Charpy V Transition Temperature in Mild Steel and Various Material Parameters," Mat. Sci. 18, 177-86 (1984).

[31] T. Naniwa, M. Shibaike, M. Tanaki, H. Tani, H. N. Shiota, and T. Shiraishi, Effects of the Striking Edge Radius on the Charpy Impact Test,"pp. 67-80 in Charpy Impact Test: Factors and Variables, ASTM STP 1072, J. M. Holt, Ed., American Society for Testing and Materials, Philadelphia, 1990.

[32] R. K. Nanstad and M. A. Sokolov, "Charpy Impact Test Results on Five Materials and NIST Verification Specimens using Instrumented 2-mm and 8-mm Strikers," pp. 111-39 in Pendulum Impact Machines: Procedures and Specimens for Verification. ASTM STP 1248, T. A. Siewert and A. K. Schmieder, Eds., American Society for Testing and Materials, Philadelphia, 1995.

[33] N. N. Davidenkov, The Problems of Impact in Material Science, Academy of Science of U.S.S.R., 1938 (in Russian).

[34] W. Weibull, "A Statistical Theory of the Strength of Materials," p. 151 in Proceedings of the Royal Swedish Institute for Engineering Research, 1939.

[35] W. Weibull, "A Survey of 'Statistical Effects' in the Field of Material Failure," Appl. Mech. Rev. 5(11), 449-51 (1952).

[36] N. Davidenkov, E. Shevandin, and F. Wittmann, "The Influence of Size on the Brittle Strength of Steel," J. Appl. Mech. 63-67 (March 1947). 